Perspective

\title{
Acute Graft-Versus-Host Disease, Prophylaxis and Therapy
}

\author{
Nidhi Sharma, Yvonne Efebera *
}

Division of Hematology, Department of Internal Medicine, The Ohio State University Comprehensive Cancer Center Columbus, Ohio, USA; E-Mails: Nidhi.Sharma@osumc.edu; Yvonne.Efebera@osumc.edu

* Correspondence: Yvonne Efebera; E-Mail: Yvonne.Efebera@osumc.edu

Academic Editor: Gerhard Hildebrandt

Special Issue: Graft-versus-Host Disease

OBM Transplantation

2021, volume 5, issue 1

doi:10.21926/obm.transplant.2101139
Received: October 26, 2020

Accepted: March 15, 2021

Published: March 25, 2021

\begin{abstract}
Graft-versus host disease is one of the major causes of death in patients undergoing allogeneic hematopoietic stem cell transplantation. Major contributing factors to severity of graft-versus host disease include HLA mismatch, conditioning regimen intensity, age of donor and recipient, source of stem cell, and donor type. Strategies and clinical trials are ongoing to reduce the incidence of graft-versus host disease, and to improve on the survival outcome of patients with graft-versus host disease, Research efforts continue to develop new ways of identification, prevention, and treatment for graft versus host disease. In addition, efforts are also being made to incorporate biomarker for the early detection of graft versus host disease. In addition, strategies utilizing monoclonal antibodies and cytokines are being tested as potential therapeutic options. Here we provide evidence for recommended regimens for graft versus host disease, prophylaxis and treatment.
\end{abstract}

\section{Keywords}

Acute Graft-versus-host Disease; GVHD; hematopoietic stem cells; transplantation

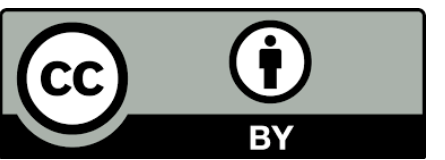

(C) 2021 by the author. This is an open access article distributed under the conditions of the Creative Commons by Attribution License, which permits unrestricted use, distribution, and reproduction in any medium or format, provided the original work is correctly cited. 


\section{Introduction}

Allogenic Hematopoietic stem cells (allo-HSCT) has become the standard of care for many patients with hematologic cancers but also for many other disorders. Over the last two decades, HSCT has seen rapid expansion with a constant evolution in technology use. Bone marrow is supplemented as a stem cell source by peripheral blood or cord blood. The advent of novel conditioning regimens with lower intensity have expanded the use of HSCT to older patients or to those with co morbidities. However, its efficacy continued to be limited by the development of frequent and severe acute graft-versus-host disease (aGVHD).

The history of GVHD dates back to the 1910s, when an immunologic reaction was observed in chick embryos [1]. At that time, the concept of T cells was new and a link between GVHD and T cells did not exist [1, 2]. Since that time, many advances have been made throughout the decades with regard to our understanding of the disease and its treatment options. A pioneering discovery by Billingham in 1966, paved the way for a deeper understanding of the pathophysiology of GVHD in the field of allo-HSCT [3]. GVHD develops in 30-75\% of recipients of allo-HSCT despite current GVHD prophylaxis. There are various risk factors for GVHD and few of the most significant factors are the degree of histocompatibility between the donor and the recipient, number of T-cells in the graft, recipient's age and GVHD prophylactic regimen used [4-6]. The interactions between the donor and host innate and adaptive immune responses leads to the development of aGVHD. The donor T cells are mainly responsible for aGVHD pathogenesis, while both the donor $\mathrm{T}$ cells and $\mathrm{B}$ cells are responsible for chronic GVHD (cGVHD)-mediated tissue injury. Despite remarkable clinical advances, GVHD remains the greatest obstacle in the success of allo-HSCT due to considerable morbidity and mortality. There are two main types of GVHD-acute and chronic-differing in the pathogenesis, time of onset, and clinical presentation. A-GVHD generally runs a limited course, whereas cGVHD may be active for years, requiring potentially years of immunosuppressive therapies and placing patients at risk for a number of late complications. Based on the timing of presentation of symptoms GVHD is classified as a) classic aGVHD (which is initial diagnosis within the first 100 days post alloHSCT or DLI infusion), b) persistent, recurrent, late onset aGVHD (occurs beyond 100 days post-alloHSCT or can be new onset of aGVHD with no prior history and with no cGVHD symptoms) [7, 8], c) classic CGVHD (may be present at any time post allo-HSCT with diagnostic and distinctive features of cGVHD), cGVHD can be de novo onset or quiescent d) Overalpap syndrome (may be present at any time post allo-HSCT with features of both cGVHD and aGVHD $[9,10]$.

Transplantation-related mortality ranges from $3 \%$ to more than $50 \%$, depending on factors related to the patient (age, sex, comorbid diseases), the disease (stage, extent of involvement, and intrinsic disease characteristics), or the transplantation procedure (time from diagnosis to transplantation, type of graft, and human leukocyte antigen (HLA) compatibility of the donor) [11]. aGVHD, and often the treatment of aGVHD, results in organ toxicity, frequent infections, malnutrition and significant morbidity, thus delaying the recovery of patients from allo-HSCT. Although aGVHD is a substantial cause of morbidity and mortality after allo-HSCT, survival outcomes have however, improved over the last few decades because of improvements in non-relapse mortality rather than relapse incidence $[12,13]$. This article aims to provide a perspective of the current prevention and management of aGVHD, highlighting both what is known and what is yet to be determined in this complex disease. 


\section{Acute GVHD}

Acute GVHD is the major complication of allo-HSCT, developing in 30-50\% of patients undergoing a matched-related or unrelated allo-HCT following standard aGVHD prophylaxis [14-16]. The pathophysiology of aGVHD is complex and the current dogma is that there is tissue damage due to conditioning that in turn activates the host antigen-presenting cells (APCs). The initial activation of host APCs by recipient conditioning in turn activates transplanted donor T lymphocytes that expand and differentiate into effector cells that mediate cytotoxicity against recipient tissues through FasFas ligand interactions, perforin-granzyme B, and cytokine production [14, 16-18]. When severe, aGVHD carries a poor prognosis, with only $25 \%$ long term survival for grade III and $5 \%$ for grade IV [15].Recent data suggests that the majority of memory $T$ cells reside in human peripheral tissues, skin, gut, liver, and lung $[19,20]$. Clinical observations suggest that skin-resident $T$ cells survive "lymphocyte-depleting" chemotherapy, as patients who are profoundly lymphopenic following chemotherapy can still develop T cell-mediated drug rashes despite the absence of circulating lymphocytes [21]. In agreement with these observations Divito et al. [22], showed that host T cells survive conditioning prior to allo-HSCT and are present in target tissues during aGVHD. The study showed a proinflammatory role for host $\mathrm{T}$ cells in peripheral tissues. In addition, a study showed selective depletion of naïve $T$ cells from human allogeneic grafts reduced the incidence of cGVHD but did not affect aGVHD [23]. It is possible that both donor and host T cells may be required for severe acute GVHD, host T cells alone may be sufficient for mild GVHD. Hence, the assumption that donor T cells are important and that T cell depletion abrogates GVHD might change in the future and needs to be further studied.

\section{Grading of aGVHD}

Acute GVHD primarily involved the skin (maculopapular erythematous skin rash), liver(hyperbilirubinemia and/or elevated liver enzymes), and gastrointestinal(GI) tract(upper and/or lower GI tract with nausea, vomiting, anorexia, weight loss, diarrhea, ileus, and/or GI bleed) and the severity is graded by evaluating these 3 target organs by pattern of their involvement, and symptoms [24-28]. The Glucksberg aGVHD classification was first proposed in the 1974 . This classification staged skin, lower gastrointestinal tract and liver, each on a scale of 0 (absent) to 4 (severe) points (Table 1 and Table 2), to create a final overall grade of I (mild) to IV (life-threatening) $[24,29]$. The Keystone aGVHD consensus panel reviewed the outcome of the Glucksberg classification in almost 6000 patients and confirmed the predictive value of maximum aGVHD grade for day 100 mortality [25] (Table 1 and Table 2). Three major recommendations resulted from the review (1) upper GI tract manifestations, in the presence of a positive biopsy, should be classified as overall grade II aGVHD; (2) GI stage 4 should be based on severe symptoms such as severe pain, bleeding and/or ileus and not diarrhea volume alone; and (3) functional status should be eliminated as an element of overall grade because it is non-specific and multiple factors play a role in functional status. The International Blood and Marrow Transplant research (IBMTR) aGVHD classification was also proposed by the Center for International Blood and Marrow Transplant Research (CIBMTR) which provided a more accurate prediction of Mortality [26] (Table 1 and Table 2). The Minnesota aGVHD grading is a further adaptation of the keystone concensus criteria. This criteria limited overall grade IV aGVHD to skin and gut stage four, instead of skin and liver stage four [28] (Table 1 and Table 2). The diagnosis should ideally be supported by histologic findings on biopsy, but this is 
not strictly necessary. Since the diagnosis is based mostly on clinical presentations and symptoms, the diagnosis, grading and percentage of aGVHD among institutions can vary, making it challenging for data interpretation, clinical comparison, and consistency [29]. The Mount Sinai Acute GVHD International Consortium (MAGIC) has revisited these criteria based on a review of their extensive database containing detailed clinical information on aGVHD, and recommended more precise definitions for grade IV aGVHD [27] (Table 1 and Table 2). 
Table 1 Comparison of staging of acute GVHD.

\begin{tabular}{|c|c|c|c|c|c|}
\hline $\begin{array}{l}\text { Organ } \\
\text { Stage }\end{array}$ & Severity & $\begin{array}{l}\text { Original } \\
\text { Critera[24] }\end{array}$ & $\begin{array}{l}\text { Modified Glucksberg or Keystone } \\
\text { Criteria[25, 26] }\end{array}$ & Minnesota Criteria[28] & MAGIC[27] \\
\hline $\begin{array}{l}\text { Skin } \\
0\end{array}$ & & No rash & No rash & No rash & No rash \\
\hline 1 & & Rash $<25 \%$ of BSA & Rash $<25 \%$ of BSA & Rash $<25 \%$ of BSA & Rash $<25 \%$ of BSA \\
\hline 2 & & Rash $25 \%$ to $50 \%$ of BSA & Rash $25 \%$ to $50 \%$ of BSA & Rash $25 \%$ to $50 \%$ of BSA & Rash $25 \%$ to $50 \%$ of BSA \\
\hline 3 & & Rash $>50 \%$ of BSA & Rash $>50 \%$ of BSA & Rash $>50 \%$ of BSA & Rash $>50 \%$ of BSA \\
\hline 4 & & $\begin{array}{l}\text { Generalized erythroderma } \\
\text { with bullous formation }\end{array}$ & $\begin{array}{l}\text { Generalized erythroderma with bullous } \\
\text { formation }\end{array}$ & $\begin{array}{l}\text { Generalized erythroderma with } \\
\text { bullous formation }\end{array}$ & $\begin{array}{l}\text { Generalized erythroderma ( }>50 \% \\
\text { BSA) plus bullous formation and } \\
\text { desquamation }>5 \% \text { of BSA }\end{array}$ \\
\hline \multicolumn{6}{|r|}{ (6) } \\
\hline 0 & & $\begin{array}{l}\text { Total serum bilirubin }<34 \text { umol } \\
(2 \mathrm{mg} / \mathrm{dl} \text {, or AST/SGOT } 150 \text { - } \\
750 \mathrm{IU}\end{array}$ & Total serum bilirubin $<2 \mathrm{mg} / \mathrm{dL}$ ) & $\begin{array}{l}\text { Total serum bilirubin }<34 \text { umol } \\
(2 \mathrm{mg} / \mathrm{dl})\end{array}$ & $\begin{array}{l}\text { Total serum bilirubin <34umol } \\
(2 \mathrm{mg} / \mathrm{dl})\end{array}$ \\
\hline 1 & & $\begin{array}{l}\text { Total serum bilirubin } 34-50 \\
\mu \mathrm{mol} / \mathrm{L}(2 \text { to } 3 \mathrm{mg} / \mathrm{dL})\end{array}$ & $\begin{array}{l}\text { Total serum bilirubin } 34-50 \mu \mathrm{mol} / \mathrm{L}(2 \\
\text { to } 3 \mathrm{mg} / \mathrm{dL} \text { ) }\end{array}$ & $\begin{array}{l}\text { Total serum bilirubin } 34-50 \\
\mu \mathrm{mol} / \mathrm{L}(2 \text { to } 3 \mathrm{mg} / \mathrm{dL})\end{array}$ & $\begin{array}{l}\text { Total serum bilirubin } 34-50 \\
\mu \mathrm{mol} / \mathrm{L}(2 \text { to } 3 \mathrm{mg} / \mathrm{dL} \text { ) }\end{array}$ \\
\hline 2 & & $\begin{array}{l}\text { Total serum bilirubin } 51- \\
102 \mu \mathrm{mol} / \mathrm{L}(3.1 \text { to } 6 \mathrm{mg} / \mathrm{dL})\end{array}$ & $\begin{array}{l}\text { Total serum bilirubin } 51-102 \mu \mathrm{mol} / \mathrm{L} \\
\text { ( } 3.1 \text { to } 6 \mathrm{mg} / \mathrm{dL} \text { ) }\end{array}$ & $\begin{array}{l}\text { Total serum bilirubin 51- } \\
102 \mu \mathrm{mol} / \mathrm{L}(3.1 \text { to } 6 \mathrm{mg} / \mathrm{dL})\end{array}$ & $\begin{array}{l}\text { Total serum bilirubin } 51- \\
102 \mu \mathrm{mol} / \mathrm{L}(3.1 \text { to } 6 \mathrm{mg} / \mathrm{dL})\end{array}$ \\
\hline 3 & & $\begin{array}{l}\text { Total serum bilirubin } 103-255 \\
\mu \mathrm{mol} / \mathrm{L}(6.1 \text { to } 15 \mathrm{mg} / \mathrm{dL})\end{array}$ & $\begin{array}{l}\text { Total serum bilirubin } 103-255 \mu \mathrm{mol} / \mathrm{L} \\
\text { ( } 6.1 \text { to } 15 \mathrm{mg} / \mathrm{dL} \text { ) }\end{array}$ & $\begin{array}{l}\text { Total serum bilirubin } 103-255 \\
\mu \mathrm{mol} / \mathrm{L}(6.1 \text { to } 15 \mathrm{mg} / \mathrm{dL})\end{array}$ & $\begin{array}{l}\text { Total serum bilirubin } 103-255 \\
\mu \mathrm{mol} / \mathrm{L}(6.1 \text { to } 15 \mathrm{mg} / \mathrm{dL})\end{array}$ \\
\hline 4 & & $\begin{array}{l}\text { Total serum bilirubin }>255 \\
\mu \mathrm{mol} / \mathrm{L}(>15 \mathrm{mg} / \mathrm{dL})\end{array}$ & $\begin{array}{l}\text { Total serum bilirubin }>255 \mu \mathrm{mol} / \mathrm{L} \text { ( }>15 \\
\mathrm{mg} / \mathrm{dL} \text { ) }\end{array}$ & $\begin{array}{l}\text { Total serum bilirubin }>255 \\
\mu \mathrm{mol} / \mathrm{L}(>15 \mathrm{mg} / \mathrm{dL})\end{array}$ & $\begin{array}{l}\text { Total serum bilirubin }>255 \mu \mathrm{mol} / \mathrm{L} \\
\text { (>15 mg/dL) }\end{array}$ \\
\hline
\end{tabular}


Upper GI

0

NA

1

\section{Lower GI}

0

1

Diarrhea $<500 \mathrm{ml} /$ day

Diarrhea $>500 \mathrm{ml} /$ day

2

3
No persistent nausea and no histologic evidence of GVHD in the stomach or duodenum

Persistent nausea with histologic evidence of GVHD in the stomach or duodenum

Diarrhea $<500 \mathrm{ml} /$ day

Diarrhea $>500 \mathrm{ml} /$ day

Diarrhea $>1000 \mathrm{ml} /$ day

Diarrhea $>1500 \mathrm{ml} /$ day

Severe abdominal pain with or without ileus

Severe abdominal pain, bleed, with or without ileus
No persistent nausea and no

histologic evidence of GVHD in No or intermittent ${ }^{a}$ a anorexia or the stomach or duodenum nausea or vomiting

Persistent nausea with

histologic evidence of GVHD in Persistent ${ }^{a}$ a anorexia or nausea

the stomach or duodenum or vomiting

Diarrhea $<500 \mathrm{ml} /$ day

Diarrhea $>500 \mathrm{ml} /$ day

Diarrhea $>1000 \mathrm{ml} /$ day

Diarrhea $>1500 \mathrm{ml} /$ day
Diarrhea $<500 \mathrm{~mL} /$ day or $<3$ episodes/day for adults ${ }^{\text {b,c }}$

Diarrhea 500-999 mL/day or 3-4 episodes/day for adults ${ }^{b, d}$

Diarrhea $1000-1500 \mathrm{~mL} /$ day or 57 episodes/day for adults ${ }^{\text {b,e }}$

Diarrhea $>1500 \mathrm{~mL} /$ day or $>7$ episodes/day for adults ${ }^{b, f}$

Severe abdominal pain with or without ileus or grossly bloody stools (regardless of stool volume)

\section{Karnofsky Index}

\section{score}


${ }^{b}$ One episode of diarrhea is considered to be about $200 \mathrm{ml}$ for an adult and $3 \mathrm{ml} / \mathrm{kg}$ for a child $(<50 \mathrm{~kg}$ ) [16]

c Diarrhea $30 \mathrm{~mL} / \mathrm{kg} /$ day or $>10$ episodes/day for children

${ }^{\mathrm{d} D i a r r h e a} 10-19.9 \mathrm{~mL} / \mathrm{kg} /$ day or 4-6 episodes/day for children

e Diarrhea $20-30 \mathrm{~mL} / \mathrm{kg} /$ day or $7-10$ episodes/day for children

${ }^{f}$ Diarrhea $>30 \mathrm{~mL} / \mathrm{kg} /$ day or $>10$ episodes/day for childre

Table 2 Comparison of grading of acute GVHD.

\begin{tabular}{|c|c|c|c|c|c|c|}
\hline $\begin{array}{l}\text { Overall } \\
\text { Glucksberg } \\
\text { MGIC Grade } \\
\end{array}$ & Glucksberg & $\begin{array}{l}\text { Modified Glucksberg or } \\
\text { Keystone Criteria[25] }\end{array}$ & Minnesota Criteria[28] & MAGIC[27] & IBMTR Criteria[26] & $\begin{array}{l}\text { Overall } \\
\text { IBMTR } \\
\text { Grade } \\
\end{array}$ \\
\hline 0 & $\begin{array}{l}\text { no organ involvement } \\
\text { (skin=0; and liver=0; and } \\
\mathrm{Gl}=0 \text { ) corresponds to the } \\
\text { absence of aGVHD }\end{array}$ & $\begin{array}{l}\text { no organ involvement } \\
\text { (skin=0; and liver=0; } \\
\text { and } \mathrm{Gl}=0 \text { ) corresponds } \\
\text { to the absence of } \\
\text { aGVHD }\end{array}$ & $\begin{array}{l}\text { no organ involvement } \\
\text { (skin=0; and liver=0; and } \\
\mathrm{Gl}=0 \text { ) corresponds to the } \\
\text { absence of aGVHD }\end{array}$ & $\begin{array}{l}\text { no organ involvement } \\
\text { (skin=0; and liver=0; } \\
\text { and } \mathrm{GI}=0 \text { ) corresponds } \\
\text { to the absence of } \\
\text { aGVHD }\end{array}$ & $\begin{array}{l}\text { no organ involvement } \\
\text { (skin=0; and liver=0; } \\
\text { and } \mathrm{Gl}=0 \text { ) corresponds } \\
\text { to the absence of } \\
\text { aGVHD }\end{array}$ & 0 \\
\hline 1 & $\begin{array}{l}\text { skin=1 or 2, without } \\
\text { liver/GI involvement or } \\
\text { decrease in performance } \\
\text { status/fever }\end{array}$ & $\begin{array}{l}\text { skin }=1 \text { or } 2, \text { without } \\
\text { liver/Gl involvement }\end{array}$ & $\begin{array}{l}\text { skin }=1 \text { or } 2 \text {, without } \\
\text { liver/GI involvement }\end{array}$ & $\begin{array}{l}\text { skin }=1 \text { or } 2, \text { without } \\
\text { liver/GI involvement }\end{array}$ & $\begin{array}{l}\text { skin=1, without liver/GI } \\
\text { involvement }\end{array}$ & A \\
\hline II & $\begin{array}{l}\text { skin=1 or } 2 \text { and (liver } \\
\text { and/or Gl involvement=1 } \\
\text { or } 2 \text { ) with mild decrease in } \\
\text { performance status }\end{array}$ & $\begin{array}{l}\text { skin=3; and/or liver=1; } \\
\text { and/or } \mathrm{GI}=1\end{array}$ & $\begin{array}{l}\text { skin=3; and/or liver=1; } \\
\text { and/or Gl=1 }\end{array}$ & $\begin{array}{l}\text { skin=3; and/or liver=1; } \\
\text { and/or Gl=1 }\end{array}$ & $\begin{array}{l}\text { skin=2; and/or liver }=1 \\
\text { or } 2 ; \text { and/or } \mathrm{Gl}=1 \text { or } 2\end{array}$ & B \\
\hline III & $\begin{array}{l}\text { (skin and/or liver and/or } \\
\mathrm{Gl}=2,3 \text { or } 4 \text { ) with marked } \\
\text { decrease in performance } \\
\text { status }\end{array}$ & $\begin{array}{l}\text { liver }=2 \text { or } 3 \text {; and/or } \\
\mathrm{GI}=2,3 \text { or } 4\end{array}$ & $\begin{array}{l}\text { liver }=2,3 \text { or } 4 \text {; and/or } \\
\mathrm{GI}=2 \text { or } 3\end{array}$ & $\begin{array}{l}\text { liver }=2 \text { or } 3 ; \text { and/or } \\
\mathrm{Gl}=2 \text { or } 3\end{array}$ & $\begin{array}{l}\text { skin=3; and/or liver=3; } \\
\text { and/or } \mathrm{Gl}=3\end{array}$ & C \\
\hline IV & & & skin $=4 ;$ and $/$ or $\mathrm{Gl}=4$ & & & D \\
\hline
\end{tabular}


OBM Transplantation 2021; 5(1), doi:10.21926/obm.transplant.2101139

(skin and/or liver and/or skin=4; and/or liver=4

$\mathrm{Gl}=2, \quad 3$ or 4) with

skin=4; and/or liver=4; skin=4; and/or liver=4

Karnofsky $<30 \%$

Page $8 / 31$ 


\section{Acute GVHD and Biomarkers}

The criteria of aGVHD are sometimes not adequate to guide treatment at symptom onset resulting in a delay in intensifying treatment. Thus, the need to develop a system to define risk across at the onset of clinical presentations is needed. Post- allo-HSCT changes in plasma proteins associated with markers of target organ damage was a valuable source to get an insight into the earliest stages of GVHD pathophysiology prior to clinical manifestations [30, 31]. The first validated test for aGVHD was measured using ELISA evaluating the levels of biomarkers in patients undergoing allo transplantation. Four biomarkers (IL-2R $\alpha$, TNFR1, IL-8, and HGF) effectively discriminated between patients with and without GVHD [32]. This biomarker panel was highly specific and predicted long-term survival independently of maximum GVHD grade. This biomarker panel provided a specific test for GVHD in the $85 \%$ of patients who do not have other major complications. Since resistance to GVHD therapy is associated with non-relapse mortality (NRM) and lower overall survival (OS). Thus, the need for biomarkers which would help with early assessment of treatment response. Also, this study lacked in comparing plasma concentrations of patients at GVHD onset with those of patients who had similar symptoms but which were from other causes. Hence, studies were done to determine organ-specific biomarkers to differentiate GVHD from other causes of similar symptoms [33]. Proteomics discovery and validation strategies were applied to identify the following biomarkers for GVHD. Tumor necrosis factor receptor-1 [TNFR1], IL-2 receptor- $\alpha$ [IL-2R $\alpha$ ], IL-8 for systemic GVHD; hepatocyte growth factor [HGF]) with diagnostic and prognostic value for acute GVHD; Elafin for skin GVHD, and REG3a-GI and ST2 for GI GVHD [32, 34-36]. No single biomarker predicted outcomes for GVHD and a panel was tested to see if it could overcome institutional effect and stratify patients for risk of NRM at 6 months. Every combination was tested and with competing regression model, biomarkers comprising of ST2, TNFR1 and REG3a was the best model and generated probability of NRM identified thresholds for Ann Arbor scores [32]. This panel possessed biological relevance to gastro intestinal GVHD which was of importance as most deaths of patients with GVHD - are due to poor response to treatment of GVHD in the gastro intestinal tract.

The Mount Sinai Acute GVHD International Consortium (MAGIC), a group of 25 HCT centers has since validated an algorithm that combines two GI biomarkers (ST2and REG3 $\alpha$ ) into a single value that estimates the probability of 6 month non-relapse mortality (NRM) for individual patients, known as the MAGIC algorithm probability (MAP). The MAP reflects GI crypt damage and serves as a 'liquid biopsy' of the lower GI tract; it also predicts response to treatment and maximum GVHD severity and is commercially available and used among centers in clinical practice [37]. This biomarker panels measured during the course of GVHD treatment provide valuable prognostic information, independent and additive to the observable clinical status of the patient at the time of measurement [38]. Limitation of MAP is that it is mostly focused on assessment of GI GVHD and not other organs such as the liver which can also be associated with high mortality. It is however being used as an affirmation of disease risk in conjunction with clinical staging to make decision on intensity of treatment. MAP was used in the BMT/CTN 1501 to confirm Minnesota low risk aGVHD in the randomized study between Prednisone and Sirolimus for low-risk aGVHD [39]. It is also been used in ongoing study for low risk aGVHD in which steroid-sparing drug such as Itacitinib, may be an optional treatment (NCT-03846479); and in ongoing study to predict patients for potential high risk GVHD and pre-emptively start them on treatment before onset of GVHD (Alpha-1-Antitrypsin NCT03459040). 


\section{Prophylaxis for GVHD}

Clinically significant grade II-IV aGVHD occurs in 34-40\% of patients undergoing HLA-matched related $\mathrm{HSCT}, 47-52 \%$ of HLA-matched unrelated and is further increased in those lacking matched donors [40-42]. Prophylaxis after allo-HSCT is an ongoing effort due to the heterogeneity in the studies with respect to the donor type and graft source.

The GVHD pharmacological prophylaxis may include calcineurin inhibitors (CNIs); cyclosporine A (CSP) and tacrolimus (TAC), the antimetabolite methotrexate (MTX), the mTOR inhibitor sirolimus, the inosine monophosphate dehydrogenase inhibitor mycophenolate mofetil (MMF) as well as antithymocyte globulin (ATG) and corticosteroids, referred to methylprednisolone, prednisolone and/or prednisone. Guidelines for GVHD prophylaxis have been proposed by the European group for Bone and Marrow Transplantation and European LeukemiaNetT [43] however, the choice of GVHD prophylaxis generally varies by institution but is consistent with bone marrow transplant clinical trials network (BMT CTN) guidelines/protocol being proposed and takes into account the disease, degree of HLA disparity, conditioning regimen and patient characteristic (Table 3) [44-46]. 
Table 3 Prophylaxis of GVHD.

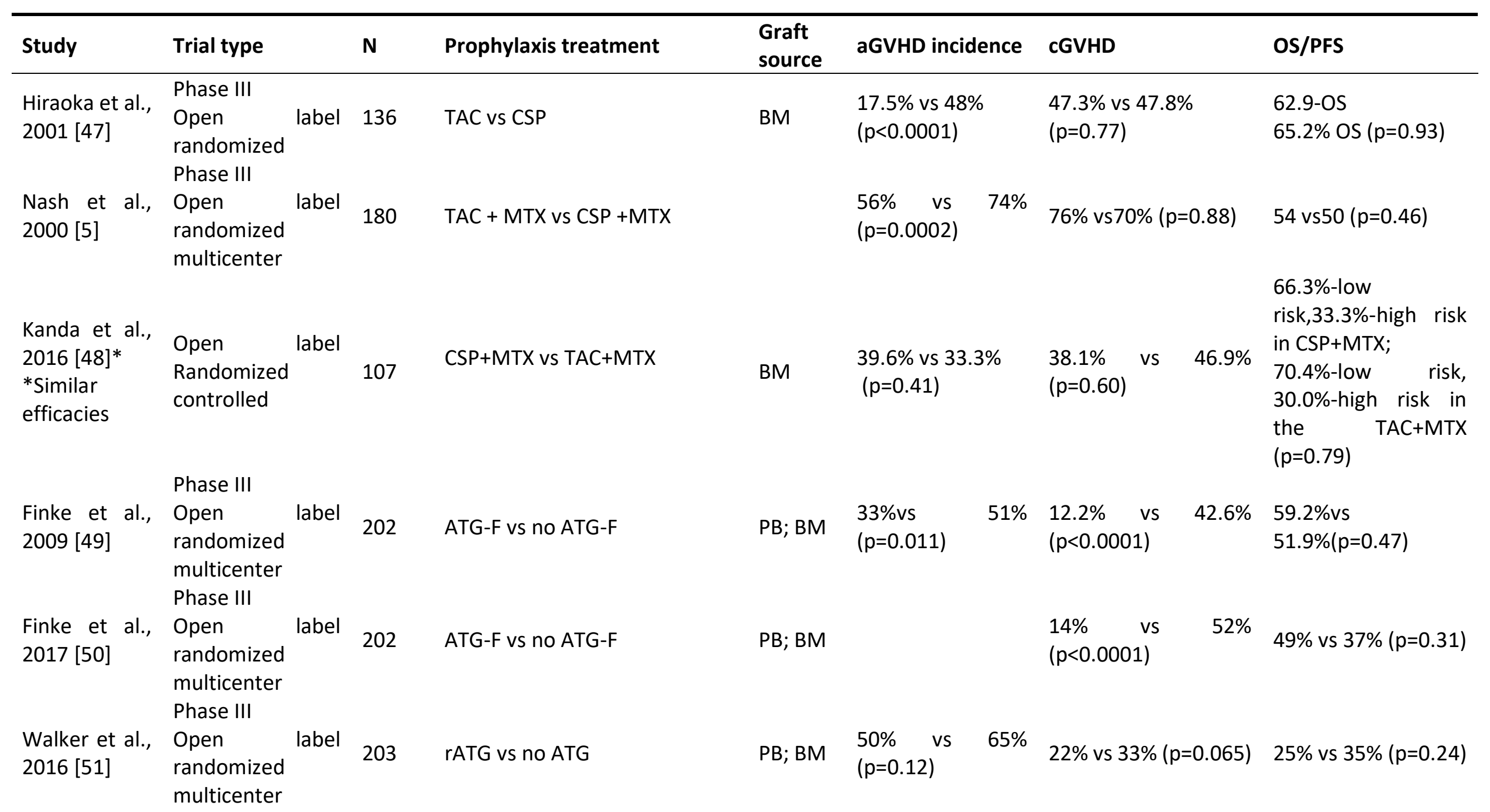




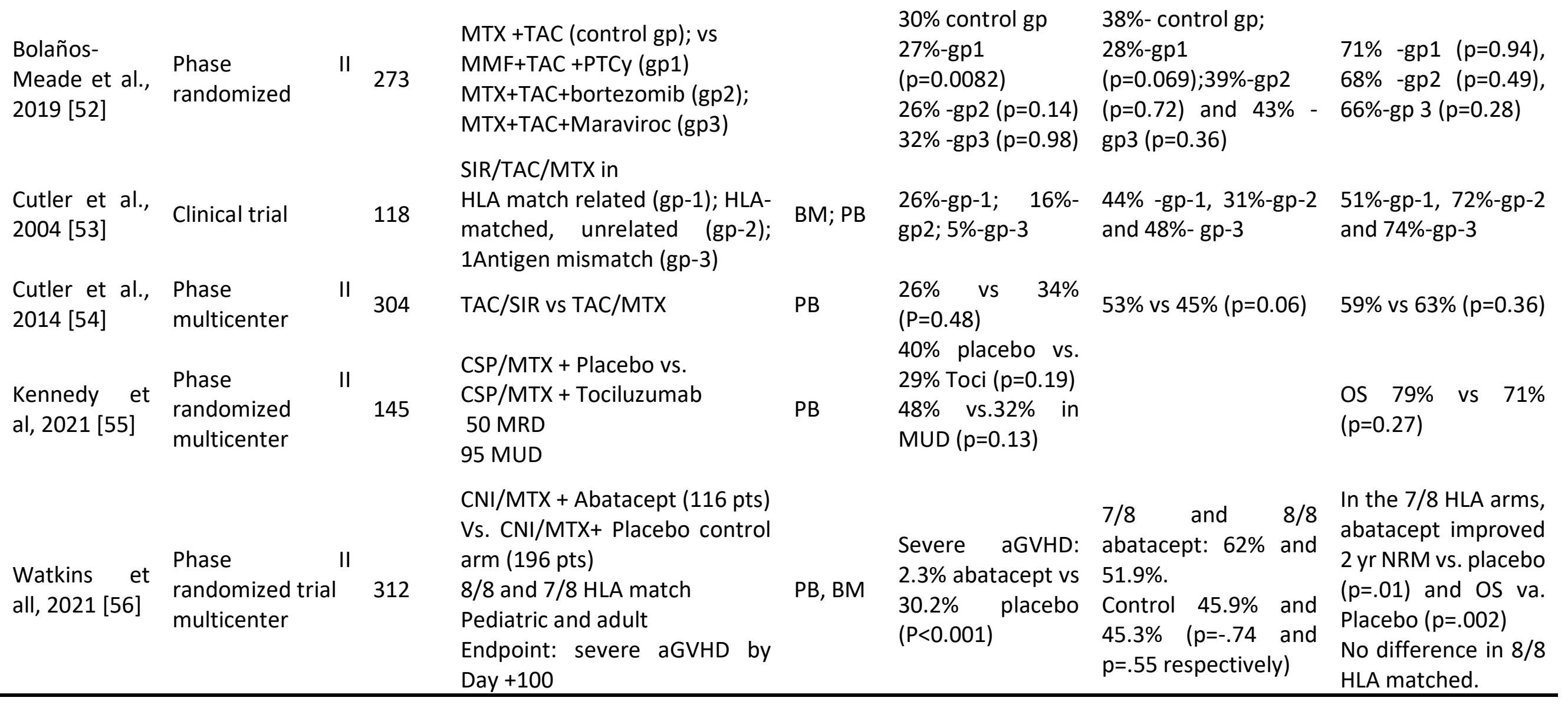

Abbreviations: TAC-tacrolimus; CSP-cyclosporine; MTX-methotrexate; MMF- mycophenolate mofetil; SIR-Sirolimus; PTCy-post-transplantation cyclophosphamide; ATG-F- Anti-T-lymphocyte globulin Fresenius; r-rabbit; gp-group.PB: peripheral Blood, BM, bone marrow, MRD matched related donor, MUD matched unrelated donor, Toci Tocilizumab. 


\subsection{Calcineurin Inhibitors (CNIs)}

Calcineurin, is an enzyme that activates T-cells of the immune system which is the cause of GVHD. Calcineurin inhibitors help in the prevention of GVHD by inhibiting this action of calcineurin. The combination of MTX and CNIs, such as TAC or CSP is the most historical and widely used regimen used for GVHD prophylaxis [57]. Although grade 2-4 aGVHD was similar with either mycophenolate mofetil (MMF) or MTX, grade 3-4 aGVHD has been shown to be higher following MMF and CNI compared to MTX and CNI. Moreover, GVHD patients develop infectious complications, and toxicity [58]. Thus, prophylaxis regimen that would minimize GVHD and other adverse events translating into better outcomes were tested. Phase III trials comparing TAC/MTX versus CSP/MTX showed incidence of grade II-IV aGVHD being 56\% in TAC/MTX versus $74 \%$ in CSP/MTX arm [5]. A metaanalysis of randomized trials showed that TAC/MTX was associated with lower aGVHD compared to CSA/MTX but there was no survival benefit of TAC/MTX, perhaps due to increased toxicity $[5,47$, 59]. However, the combination of TAC/MTX remains a standard for GVHD prophylaxis with myeloablative (MA) conditioning in the U.S, despite its limited efficacy. The common practice is to use MMF in reduced intensity conditioning (RIC). In a prospective randomized phase 2 trial with RIC, patients were randomly assigned to one of the 3 arms: TAC/MTX/bortezomib , TAC/MTX/ maraviroc and TAC/MMF/cyclophosphamide(PT-CY) [52]. The purpose of this study was to find the best prophylaxis arm to compare with the most used standard prophylaxis TAC/MMF. TAC/MMF/PT-CY) yielded the best GVHD-free-relapse free survival (GRFS) outcome [52]. TAC/MMF/PT-CY is now being prospectively compared with TAC/MTX in a phase 3 randomized trial (BMT CTN 1703) (NCT03959241) for patients undergoing RIC allo-HSCT to determine the best GVHD prophylaxis regimen in this patient population. The combination of $\mathrm{MTX/CNI}$ has been widely used but despite this GVHD remains a significant barrier to allo-HSCT with mismatched unrelated donors (MMUD). A phase I/II trial evaluated a bortezomib based regimen for controlling GVHD after MMUD [60]. In this study bortezomib, administered once per day after peripheral blood (PB) grafts plus standard TAC/MTX. GVHD incidence was low and survival outcomes were comparable to those observed in HLA matched transplants. Adding a T-cell costimulation blockade abatacept to CNI/MTX was recently published in a phase II randomized trial [56], showing that abatacept improved severe aGVHD survival (sGFS) compared to placebo. $S$ In $8 / 8$ s, grade 3-4 aGVHD was $6.8 \%$ (abatacept) versus $14.8 \%$ (placebo) $(\mathrm{P}=.13$ ). SGFS was $93.2 \%$ (CNI/MTX plus abatacept) versus $82 \%$ (CNI/MTX plus placebo, $\mathrm{P}=.05$ ). In the smaller $7 / 8$ cohort, grade $3-4$ AGVHD was $2.3 \%$ (CNI/MTX plus abatacept, intention-to-treat population), which compared favorably with a nonrandomized matched cohort of CNI/MTX (30.2\%, P, .001), and the SGFS was better $(97.7 \% \vee 58.7 \%, P, .001)$. Immunologic analysis revealed control of T-cell activation in abatacept treated patients (Table 3). A phase III double-blind trial with Tocilizumab (Toci) or placebo with MTX/CNI in 145 patients (50 matched related donor (MRD) and 95 matched unrelated donor (MUD)) was recently published [55]. The incidence of grade II-IV aGVHD at day 180 for the entire cohort was $40 \%$ placebo versus $29 \%$ Toci $(p=0.19)$ and $48 \%$ versus $32 \%$ (HR 0.59; $C l: 0.30-1.16, p=0.13)$ for the MUD subgroup. Reductions in aGVHD were predominantly in grade II disease. A trend to improved aGVHD-free survival (aGVHDFS) was noted in the Toci treated MUD group with $52 \%$ placebo $68 \%$ toci $(p=0.13)$. -For entire cohort, overall-survival was $79 \%$ versus $71 \%(p=0.27)$ respectively. Hence, while Toci had a non-significant trend towards mostly grade II aGVHD and GVHD-FS, there was no improvement in overall survival [55](Table 3). CSA and TAC are considered equivalent and there has been discussions on the target serum concentrations. It has been shown that the target concentrations of TAC in the first 4 weeks 
post-ASCT were associated with GVHD $[48,61]$. For CSP-A, concentrations of 200-300 $\mu \mathrm{g} / \mathrm{L}$ are usually recommended when the total daily dose is divided into 2 doses 12 hours apart $f$ for preventing aGVHD [43]. Low levels of CSP-A early after allo-HSCT and TAC has been shown in acute myeloid leukemia patients [62-65]. On the other hand the target ranges of the blood concentration of TAC in the first 4 weeks post transplantation have varied significantly among studies $[5,59]$. These studies have also emphasized the importance of adjusting dose levels to avoid toxicity [66, 67]. Przepiorka et al. [67] reported that mean TAC levels $>20 \mathrm{ng} / \mathrm{ml}$ is associated with increased risk of creatinine $>2 \mathrm{mg} / \mathrm{dl}$. A study in the adult population reported that the early post-transplantation blood concentrations of TAC had a significant impact on the development of aGVHD with another reporting TAC level of $<5 \mathrm{ng} / \mathrm{ml}$ was associated with increased acute GVHD $[68,69]$. In an attempt to understand the impact of early TAC levels on aGVHD incidence, Ganetsky et al. [61] showed that TAC concentration $\geq 12 \mathrm{ng} / \mathrm{ml}$ during the first week post-transplantation was associated with reduced risk of aGVHD. In our institutional study with approx. 700 patients, we found that week 1 TAC levels $\geq 10.15 \mathrm{ng} / \mathrm{ml}$ were associated with a lower risk of grade II-IV and III-IV aGVHD (manuscriptaccepted, Cancers, 2021). However, many factors need to be taken in consideration with adjusting $\mathrm{Cl}$ dose based on drug levels including drug-drug interactions, serum creatinine, and appropriate logistics of the levels being drawn.

This also holds true for recipients lacking HLA-matched donors. A phase I/II trial evaluated a bortezomib based regimen for controlling GVHD after mismatched unrelated donor (MMUD) [60].

\subsection{Sirolimus (SIR)}

SIR is structurally similar to TAC but with different mechanism of action. It is a rapamycin inhibitor which binds to FK binding protein 12 complex with mammalian target of rapamycin (mTOR), a protein kinase that regulates mRNA translation and protein synthesis, an essential step in cell division and proliferation [70]. The FKBP12-mTOR complex inhibits IL-2 mediated proliferation signaling, with a reduction in DNA transcription, DNA translation, protein synthesis and cell cycling, ultimately leading to T-cell immunosuppression [53]. PTEN/PI3 kinase/Akt and the Janus kinase, are the upstream pathways which interact with mTOR and are important in mediating IL-2-driven signaling from the T-cell receptor [71]. SIR appears to exert some of its immunosuppressive properties via inhibition of dendritic cell activity through a reduction in antigen uptake [72], cellular maturation [73], intracellular signaling [74] and apoptosis induction in dendritic cells [75]. SIR and CNIs, they seem to work synergistically, because SIR does not interact with calcineurin or its downstream effectors [76].

The combination of SIR and TAC, when compared with combination of SIR and CSP, has demonstrated higher efficacy and lower toxicity profile [77-79]. In initial studies evaluating its role, as a GVHD prophylaxis, SIR was administered as a $12 \mathrm{mg}$ oral loading dose on day -3 , followed by a $4 \mathrm{mg} /$ day single dose, with a target serum concentration of $3-12 \mathrm{ng} / \mathrm{mL}[6,53]$. In 3 clinical trials, the combination of SIR, TAC and MTX $(5 \mathrm{mg} / \mathrm{m} 2$ day $+1,3,6$ and 11$)$ was used as GVHD prophylaxis. In the HLA matched, related donor setting, patients who underwent PB stem cell transplantation received SIR/TAC without MTX as GVHD prophylaxis with MA conditioning [80]. The hypothesis here was that omitting MTX will not increase the rate of GVHD and will reduce TRM. In the HLA matched, unrelated donor setting SIR/TAC and low dose of MTX was used with MA conditioning $[6,81,82]$. In the single antigen mismatch, SIR/TAC and low dose MTX was used with non-MA conditioning. In these studies, sirolimus was shown to have a reduced incidence of aGVHD and toxicity after match 
related and match unrelated transplants. It was also shown to be effective with both non-MA and RIC regimens [53].

TAC/MTX combination has been used widely but as MTX is known to have delayed neutrophil and platelet engraftment along with toxicity, it has been implicated in initiating toxicity. BMT-CTN 0402 was a phase III, multicenter trial which sought to determine if TAC/ SIR would lead to better GVHD and TRM outcomes compared to TAC/MTX. In this study, 114 days from the time of randomization, TAC/SIR prophylaxis provided equivalent GVHD-free survival when compared with TAC/MTX in MRD transplantation. However, TAC/ SIR was associated with more rapid engraftment and reduced oropharyngeal mucositis after MRD transplantation [54]. Thus, it was concluded that TAC/ SIR is an acceptable alternative to TAC/MTX after MRD HSCT and could be considered in patients at a high risk for oropharyngeal mucositis or higher risk of infection. SIR with MTX is associated with an increased incidence of VOD. Mortality after VOD diagnosis was unaffected, and overall treatment-related mortality was lowest when SIR was used without MTX. Similar findings were noted in MRD, and MUD as well as MMUD subgroups [83]. The Blood and Marrow Transplant Clinical Trials Network conducted a multicenter, randomized phase III trial comparing SIR/TAC vs MTX/TAC after HLA-matched, related (MRD) PB HSCT [54]. SIR/TAC showed more rapid engraftment and less oropharyngeal mucositis compared to MTX/TAC. SIR based prophylaxis regimens have also been shown for haploidentical, single HLA antigen mismatched related and matched unrelated transplantation (MUD). SIR has been shown to synergistically enhance immunosuppressive effects of CSP-A and TAC. SIR is not neurotoxic and seems to have minimal renal toxicity [84, 85], enhancing CNI-induced nephrotoxicity [86]. SIR may be implicated as a cause of thrombotic microangiopathy (TMA) [87]. Robson et al. [88] reported four renal transplant patients who developed TMA soon after the introduction of SIR into their immunosuppression protocol. In contrast to CNIs, no TMA was observed when SIR was combined with MMF for GVHD prophylaxis [70, 85, 86]. SIR combined with CNIs, increased incidences of TMA and possibly veno-occlusive disease (VOD) have been observed [89]. SIR may promote TMA via direct endothelial cell damage or potentiation of CNIs effects [88]. However, TMA related to SIR monotherapy has been less commonly reported [90].

\section{T Cell Depletion}

\subsection{Post-Transplantation Cyclophosphamide (PTCy)}

Initially developed for prophylaxis in the setting of a haploidentical transplant, the use of this regimen has gained widespread acceptance as an accepted approach in multiple types of allogeneic transplantation. It has been used for prevention of GVHD in HLA-matched and mismatched, as well as with both MA and non-MA regimens [91-94]. PTCy has been shown to have reduced incidences of lymphoproliferative disorders and lower grades 3-4 aGVHD and cGVHD by depleting alloreactive T cells in the host and/or support T cell mediated tolerance $[95,96]$. Studies have shown that Cy as a single agent or together with MMF and TAC/CSP is safe and effective for lowering aGVHD and cGVHD with T cells replete grafts from partially HLA mismatched related donors [91, 94, 97, 98]. Recently, in a phase II randomized trial tested three approaches for GVHD prophylaxis (TAC, MMF, and PTCy; TAC, MTX, and bortezomib;and TAC, MTX, and maraviroc), comparing each to a nonrandomized contemporary cohort using a novel endpoint assessing GVHD relapse and survival. All patients received received RIC conditioning with MRD or MUD donors. High-dose PTCy-based regimen was shown to be effective versus MTX and CNI for GVHD prophylaxis [52]. 


\subsection{Anti-T-Lymphocyte Globulin (ATG)}

Allo-HSCT is increasingly used as a treatment for patients with life threatening blood diseases. The success of this is based on immune-based graft versus leukemia effect caused by donor T cells. But donor T-cells are also the cause of GVHD. Allo- HSCT are done using PB instead of bone marrow (BM) as the graft source. PB has the advantage of more hematopoietic stem cells but also it has more T cells. This causes higher incidences of both aGVHD and cGVHD. These observations have led to various studies aiming at assessing the impact of immunoregulation with ATG on transplantation outcomes. A better understanding of the pathobiology behind the GVHD process has thus led the way to novel approaches and medications. Adding ATG in one of its three commercially available preparations (Thymoglobulin, ATGAM, and ATG-Fresenius) for in vivo T-cell depletion has been shown to decrease the incidence of aGVHD and cGVHD, with mixed effects on disease relapse [49, 99-101] [102]. However, due to the differences in preparations and dose of ATG, it has been difficult to compare outcomes between them [101]. Initially, a high dose $(10 \mathrm{mg} / \mathrm{kg})$ of thymoglobulin was utilized but it had a high incidence of relapse [103]. Remberger et al., evaluated four different doses of ATG to determine the optimal dose in patients who matched unrelated transplants [104]. The authors showed a dose dependent effect of ATG on aGVHD. However, higher doses also led to increased infection rate. In fact, the best results were seen with intermediate doses $(6 \mathrm{mg} / \mathrm{kg}$, $8 \mathrm{mg} . \mathrm{kg}$ ) as reduced risk of GVHD was seen without a substantial risk of infections [104]. Recently, we reported aGVHD incidence to be higher at $4.5 \mathrm{mg} / \mathrm{kg}$ versus $6 \mathrm{mg} / \mathrm{kg}$. There was a significant reduction in the cumulative incidence of aGVHD grade II-IV in the dose with $6 \mathrm{mg} / \mathrm{kg}$ ATG compared to $4.5 \mathrm{mg} / \mathrm{Kg}$ [105]. There was no difference in relapse, progression free survival (PFS), non-relapse mortality (NRM), and overall survival (OS). But there was a significantly decreased risk in the incidence of cytomegalovirus (CMV) and epstein barr virus (EBV) reactivation at 180 days in the $4.5 \mathrm{mg} / \mathrm{kg}$ group compared to the $6 \mathrm{mg} / \mathrm{kg}$ group. ATG works through multiple mechanisms including T-cell depletion in the blood and lymphoid tissues by induction of apoptosis or complementdependent lysis, apoptosis of naïve B cells, activated B-cells and plasma cells [106, 107], and by induction of regulatory T-cells, and natural killer (NK) cells [108] These effects could potentially lead to serious infections such as CMV and EBV, and possibly to disease relapse [109, 110]. The addition of ATG to other GVHD prophylaxis regimens decreases the cumulative incidence of cGVHD and allows more patients to discontinue pharmacologic prophylaxis for aGVHD, but has not demonstrated a survival benefit. The optimal indication, dosing regimen, time point of application is still a matter of debate. Given the heterogeneity of the patients undergoing allo-HSCT, there may not be a single, optimal dose. Instead, ATG-T dosing may depend on intensity of the preparative regimen, donor characteristics, and recipient lymphocyte counts.

\section{Treatment for Acute GVHD}

The mainstay of treatment of aGVHD is high-dose corticosteroids (methylprednisone or prednisone) [28, 111-114] (Table 2). One of the first studies assessing the efficacy of Steroids in treating aGVHD was a randomized study comparing methylprednisone (MP) $2 \mathrm{mg} / \mathrm{kg}(\mathrm{n}=47)$ versus $10 \mathrm{mg} / \mathrm{kg}(\mathrm{n}=48)$, given for 5 days with subsequent tapering [111]. Primary endpoints were response to treatment and evolution of aG-VHD to grade III-IV. The study showed no difference in response (68\% vs. $71 \%$ ), evolution to aGVHD grade III-IV (17\% vs.20\%), CMV infections (55\% vs. 60\%), Treatment related mortality (TRM) ( $28 \%$ vs. $32 \%)$ and $3-y r$ OS (63\% vs. $62 \%)$. Hence an initial dose 
of MP $2 \mathrm{mg} / \mathrm{kg}$ or the equivalent of Prednisone became the standard of care for first line therapy of aGVHD grade II-IV. The addition of Ruxolitinib to steroids for aGVHD in haploidentical transplant was a phase II study in 32 patients. The overall CR at day 56 was 96.8\% [115]. We hope a phase III study is forthcoming. A phase III placebo controlled randomized trial comparing Steroids +/Itacitinib has finished accrual in July 2020 and we await results (ClinicalTrials.gov Identifier: NCT03139604). The addition of other agents to steroids as first line treatment in aGVHD have been investigated, and none have shown a statistically significant outcome compared to steroids alone $[114,116,117]$ (Table 4). 
Table 4 aGVHD treatment: Randomized studies.

\begin{tabular}{|c|c|c|c|c|c|c|}
\hline $\begin{array}{l}\text { Study and trial } \\
\text { type }\end{array}$ & $\begin{array}{l}\text { aGVHD } \\
\text { requirement }\end{array}$ & $\mathbf{N}$ & $\begin{array}{l}\text { Steroid given and } \\
\text { dose }\end{array}$ & $\begin{array}{l}\text { Experimental } \\
\text { agent }\end{array}$ & $\begin{array}{l}\text { Prior } \\
\text { prophylaxis }\end{array}$ & $\begin{array}{l}\text { Response- standard vs. Experimental arm } \\
\text { Day } 28 \text { or } 56\end{array}$ \\
\hline $\begin{array}{l}\text { Van Lint, } 1998 \\
{[111]} \\
\text { Randomized }\end{array}$ & Grade II-IV & 95 & MP 2 mg/kg (n=47) & $\begin{array}{l}\mathrm{MP} \\
(\mathrm{n}=48)\end{array}$ & $\begin{array}{l}\text { CSA: } 53 \% \\
\text { CSA/MTX } 47 \%\end{array}$ & $\begin{array}{l}\text { ORR: } 68 \% \text { vs. } 71 \% \\
\text { aGVHD III-IV develop } 17 \% \text { vs. } 20 \% \\
3 y r \text { OS } 63 \% \text { vs. } 62 \% \\
\text { Overall no difference }\end{array}$ \\
\hline $\begin{array}{l}\text { Cragg } 2000[118] \\
\text { Randomized }\end{array}$ & Grade II-IV & 96 & $\begin{array}{l}\text { Prednisone } 60 \mathrm{mg} / \mathrm{m}^{2} \\
\times \quad 7 \text { d then taper } \\
(n=46)\end{array}$ & $\begin{array}{l}\text { Prednisone } \\
20 \mathrm{mg} / \mathrm{m} 2+\text { ATG } 15 \\
\mathrm{mg} / \mathrm{kg} \text {. Bid }\end{array}$ & $\begin{array}{l}\text { MTX/CSA:53\% } \\
\text { MTX/ATG/Pred }\end{array}$ & $\begin{array}{l}\text { ORR } 78 \% \text { both groups } \\
\text { CMV infection } 22 \% \text { vs. } 44 \% \\
\text { Pneumonitis } 24 \% \text { vs. } 50 \% \\
2 \text { yr OS similar. ATG added no benefit }\end{array}$ \\
\hline $\begin{array}{l}\text { Lee, } 2004 \text { [119] } \\
\text { Randomized }\end{array}$ & Grade II-IV & 102 & $\mathrm{MP} 2 \mathrm{mg} / \mathrm{kg}$ & $\begin{array}{lr}\text { MP } \quad 2 & \mathrm{mg} / \mathrm{kg} \\
+ \text { Daclizumab } & 1 \\
\mathrm{mg} / \mathrm{kg}\end{array}$ & NA & $\begin{array}{l}\text { Study halted after a planned interim analysis } \\
\text { showed worse } 100 \mathrm{~d} \text { survival in daclizumab } \\
\text { arm } 77 \% \text { vs. } 94 \% \\
1 \text {-yr OS } 29 \% \text { vs. } 60 \% \text {. Daclizumab was } \\
\text { detrimental }\end{array}$ \\
\hline $\begin{array}{l}\text { Couriel, } 2009[120] \\
\text { Randomized }\end{array}$ & Grade II-IV & 63 & MP 2 mg/kg & $\begin{array}{l}\text { MP } \quad 2 \quad \mathrm{mg} / \mathrm{kg} \quad+ \\
\text { Infliximab } 10 \mathrm{mg} / \mathrm{kg}\end{array}$ & Tacro/MTX 88\% & $\begin{array}{l}\text { ORR } 58 \% \text { vs. } 62 \% \\
\text { OS } 32 \% \text { vs. } 38 \% \\
\text { NRM } 36 \% \text { vs. } 52 \%(p=0.3) \\
\text { No Benefit with adding Infliximab }\end{array}$ \\
\hline $\begin{array}{l}\text { Alousi, } 2009 \text { [114] } \\
\text { Randomized } 4 \text { - } \\
\text { arm }\end{array}$ & Grade II-IV & 180 & $\begin{array}{l}\text { Historic Data with } \\
\text { Steroid alone at } \\
\text { 28day with CR 35\% }\end{array}$ & $\begin{array}{l}\text { MP } 2 \mathrm{mg} / \mathrm{kg} \text { (or pred } \\
2.5 \quad \mathrm{mg} / \mathrm{kg})+ \\
\text { etanercept or } \\
\text { MMF, or denileukin } \\
\text { or Pentostatin }\end{array}$ & $\begin{array}{l}\text { MMF based } 24 \% \\
\text { (randomized to non- } \\
\text { MMF arm) }\end{array}$ & $\begin{array}{l}\text { CR: etabercept } 26 \% \text {, MMF } 60 \% \text {, denileukin } \\
53 \% \text {, penrostatin } 38 \% \text {. } \\
\text { Severe infections: } 48 \% \text { vs. } 44 \% \text { vs. } 62 \% \\
\text { vs. } 57 \% \text {. } \\
\text { Efficacy and toxicity data suggest use of } \\
\text { MMF plus steroid to compare to steroid } \\
\text { alone }\end{array}$ \\
\hline $\begin{array}{l}\text { Balanos-Meade } \\
\begin{array}{ll}{[113],} & 2014 . \\
\text { BMT/CTN } 0802 .\end{array} \\
\text { Randomized }\end{array}$ & $\begin{array}{l}\text { Any Grade } \\
\text { requiring systemic } \\
\text { treatment }\end{array}$ & 235 & $\begin{array}{lr}\text { Prednisone } & 2 \\
\mathrm{mg} / \mathrm{kg} \text { (or } \mathrm{MP} & 1.6 \\
\mathrm{mg} / \mathrm{kg} \text { ) } & \end{array}$ & $\begin{array}{l}\text { Steroid +MMF } 1000 \\
\text { mg (or } 20 \mathrm{mg} / \mathrm{kg} \text { ) } \\
\text { every } 8 \mathrm{hrs}\end{array}$ & $\begin{array}{l}\text { No prior MMF } \\
\text { allowed within } 7 \text { days }\end{array}$ & $\begin{array}{l}\text { Day } 56 \text { GVHD-free survival grade III-IV } 51.2 \% \\
\text { vs } 54.1 \% \text {; CR } 53.8 \% \text { vs. } 60.3 \% \text {. No diff } \\
\text { CGVHD. } \\
\text { Stopping rule for Futility triggered after } 2^{\text {nd }} \\
\text { interim analysis. MMF did not add ant } \\
\text { benefit to steroid alone }\end{array}$ \\
\hline
\end{tabular}


OBM Transplantation 2021; 5(1), doi:10.21926/obm.transplant.2101139

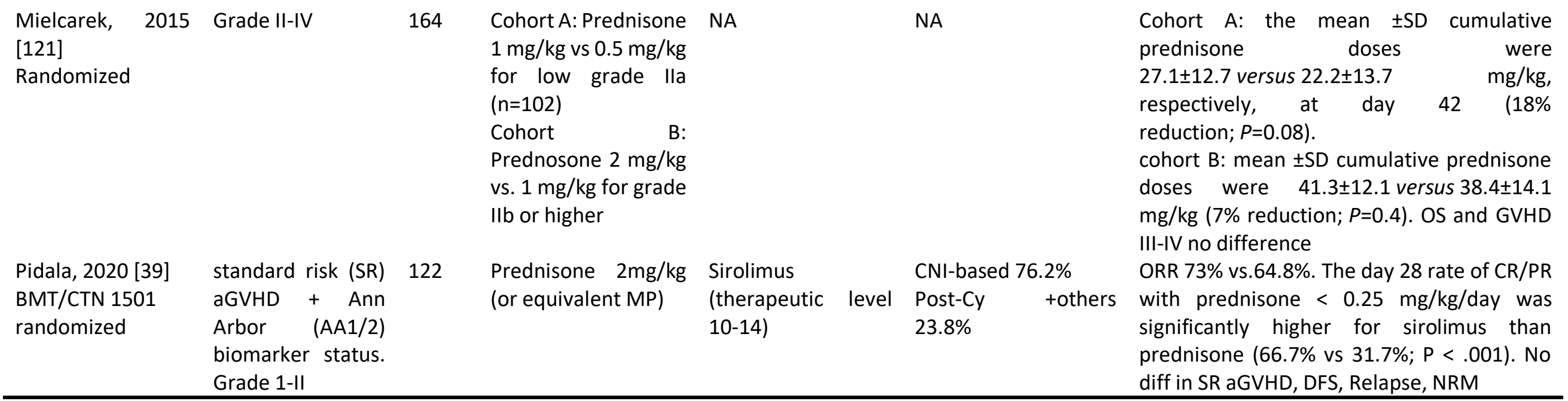

MP stands for methylprednisone; CSA cyclosporine; MTX methotrexate; ORR overall response; OS overall survival; Pred prednisone; ATG antithymocyte globulin; CMV cytomegalovirus; Tacro tacrolimus; MMF mycophenolate Mofetil; NA not applicable/not available; CNI calcineurin inhibitor; Cy clclophosphamide; SR steroid refractory; DFS disease free survival; NRM non-relapse mortality 
High dose steroids has toxicity risks such as infections, hyperglycemia, severe muscle weakness and deconditioning. Hence, the need for even lower doses of steroids less than $2 \mathrm{mg} / \mathrm{kg}$ is being sought. Unfortunately, there are paucity of Data as to the ideal dose, especially in patients with grade III-IV aGVHD. An area of consideration is to treat patients with less severe acute GVHD-grade II- with doses of MP or prednisone less than $1 \mathrm{mg} / \mathrm{kg} / \mathrm{day}(0.5 \mathrm{mg} / \mathrm{kg} / \mathrm{day})$ while reserving the higher dose ( $2 \mathrm{mg} / \mathrm{kg} /$ day) in higher grades, thus reducing toxicity while maintaining efficacy. The study by Mielcarek et al tried to answer this [121]. Patients with acute GVHD grade II with symptoms that included the upper GI (nausea, vomiting, anorexia), or lower GI but stool volume less than $1 \mathrm{~L}$ per day, or skin rash $<50 \%$ of the body surface (acute GVHD grade Ila) were treated with either 0.5 $\mathrm{mg} / \mathrm{kg} /$ day or $1 \mathrm{mg} / \mathrm{kg} /$ day. Patients with hepatic involvement (defined as total serum bilirubin $>2$ $\mathrm{mg} / \mathrm{dl}$ ) or stool volume $>1 \mathrm{~L} /$ day or skin rash $\geq 50 \%$ of the body surface area (acute grades IIb-IV) received either $1 \mathrm{mg} / \mathrm{kg} /$ day or $2 \mathrm{mg} / \mathrm{kg} /$ day. In patients with acute GVHD grade Ila, no differences in OS or progression to grades III-IV acute GVHD were found. However, in patients with grades IIb$\mathrm{IV}$, patients receiving an initial treatment of $1 \mathrm{mg} / \mathrm{kg} /$ day had a higher likelihood of requiring additional immunosuppression than those who received $2 \mathrm{mg} / \mathrm{kg}(41 \%$ vs $7 \%, \mathrm{p}=0.001)$. This supports the idea that patients with lower risk aGVHD may be safely treated with lower dose of steroids (MP 0.5-1.0 mg/kg or Prednisone equivalent) [121].

In addition to lower dose steroids for Minnesota low grade aGVHD, a second strategy is a steroidfree approach, especially for these patients who also have low Ann Arbor risk score. The BMT/CTN 1501 tried to answer this using both staging system [39]. The Minnesota (MN) Risk Score uses organ involvement and severity to identify standard-risk (SR) versus high risk(HR) $[10,122,123]$. The Ann Arbor (AA) biomarker risk score has been validated in multicenter studies [38, 124]. BMT/CTN 1501 randomized patients with both Minnesota SR and AA score of 1-2 to receive either Prednisone (2 $\mathrm{mg} / \mathrm{kg}$ ) or Sirolimus (targeted level $10-14 \mathrm{ng} / \mathrm{ml}$ ). The Primary endpoint was day-28 complete and partial response (CR and PR). The day $28 \mathrm{CR} / \mathrm{PR}$ rates were similar for sirolimus $64.8 \%$ vs $73 \%$ for prednisone. At 12 months, no differences were detected in steroid-refractory acute GVHD, diseasefree survival, relapse, non-relapse mortality, or overall survival. Sirolimus was associated with reduced steroid exposure and hyperglycemia, reduced grade 2 to 3 infections, improvement in immune suppression discontinuation and patient-reported quality of life. Increased risk for thrombotic microangiopathy was higher with Sirolimus. Hence, the conclusion was for patients with clinical- and biomarker-based SR acute GVHD, sirolimus is a viable alternative to prednisone [39]. For now, there are no Clinical trials assessing steroid-free management for Minnesota and Ann Arbor high-risk aGVHD, and high dose steroids (1-2 $\mathrm{mg} / \mathrm{kg}$ ) remain first line treatment.

\section{Treatment of Steroid-Refractory Acute GVHD}

Despite aggressive treatment with high dose steroids, only $35-40 \%$ of patients will achieve durable responses. For patients who fail to respond or progress after initiation of corticosteroids, steroid-refractory aGVHD is associated with high rates of mortality, primarily from infections and/or multi-organ failure $[15,125]$. Steroid-refractory aGVHD is characterized by progression after 3 days of high-dose steroids, involvement of new organ, no improvement after 7 days of high dose steroid for grade III aGVHD or persistent GVHD after 14 days of high-dose steroids $[112,126]$. Until recently, there was no standard therapy for steroid refractory aGVHD or head-to-head clinical trials comparing agents. Off-label retrospective analysis and small prospective studies have included 
treatments such as Etanercept, ATG, infliximab, basiliximab, alemtuzumab, mycophenolate mofetil(MMF), methotrexate, sirolimus, daclizumab, denileukin diftitox, mesenchymal stromal cells, and extracorporeal photophereis, all with variable responses [112]. Cytokines are among the critical effector molecules involved in GVHD pathogenesis and their kinetic pattern of expression is different in various affected tissues [127]. Newer agents that target GI GVHD such as tocilizumab, vedolizumab, alpha-1 antitrypsin and itacitinib are being explored with small prospective and retrospective studies showing varying responses based on organ involvement [128-132]. It remains to be seen whether these or other strategies will have a significant benefit on the long-term outcomes of GI GVHD. These agents were discussed in detail in a recent publication in pharmacotherapy [130].

The only approved drug for steroid-refractory aGVHD is Ruxolitinib based on the REACH 1 and REACH 2 trials $[133,134]$ In the phase 2 REACH 1 trial, patients aged at least 12 years with grades II to IV steroid-refractory aGVHD were eligible to receive ruxolitinib orally, starting at $5 \mathrm{mg}$ twice daily (increase to $10 \mathrm{mg}$ twice daily after 3 days in absence of cytopenia) plus corticosteroids (methylprednisone $2.0 \mathrm{mg} / \mathrm{kg} /$ day or prednisone $2.5 \mathrm{mg} / \mathrm{kg} /$ day with tapering per institution guideline), until treatment failure, unacceptable toxicity, or death. The primary end point was overall response rate (ORR) at day 28; the key secondary end point was duration of response (DOR) at 6 months. Forty-eight of the 71 patients enrolled had grade III/IV aGVHD. At day 28, 39 patients (54.9\%) had an overall response, including 19 (26.8\%) with complete responses. Best ORR at any time was $73.2 \%$ (complete response, 56.3\%). Responses were observed all across skin (61.1\%), upper (45.5\%) and lower (46.0\%) gastrointestinal tract, and liver (26.7\%). Median DOR was 345 days. Overall survival estimate at 6 months was 51.0\%. At day 28, 24 (55.8\%) of 43 patients receiving ruxolitinib and corticosteroids had a $50 \%$ or greater corticosteroid dose reduction from baseline. In a post hoc model-based analysis, grade II vs. grade III/IV aGVHD was significantly associated with day 28 response $(P=.0042)$. The most common treatment-emergent adverse events were anemia (64.8\%), thrombocytopenia (62.0\%), hypokalemia (49.3\%), neutropenia (47.9\%), and peripheral edema (45.1\%) [133]. The ORR was durable with encouraging survival compared with historical data in these patient population.

The REACH 2 trial randomized 309 patients with steroid-refractory grade II-IV aGVHD to ruxolitinib(10 mg twice a day) or investigators choice of control therapy [134]. The type of control therapy was chosen by the investigator at the time of randomization from the following options: antithymocyte globulin, extracorporeal photopheresis, mesenchymal stromal cells, low-dose methotrexate, mycophenolate mofetil, mammalian target of rapamycin (mTOR) inhibitor (everolimus or sirolimus), etanercept, or infliximab. Crossover from control therapy to ruxolitinib therapy was permitted if patients did not have a response at day 28 or if they had a loss of response thereafter and received additional systemic therapy and did not have signs of chronic GVHD. Standard supportive therapy (including growth factors, anti-infective medication, transfusion support, and other standard supportive care measures) was allowed in both treatment groups in addition to the continued use of calcineurin inhibitors and glucocorticoids. ORR at day 28 was higher in the ruxolitinib group than in the control group ( $62 \%$ vs. $39 \%, p<0.001)$. DOR at day 56 was higher in the ruxolitinib group than in the control group ( $40 \%$ vs. $22 \%, p<0.001$ ). The estimated cumulative incidence of loss of response at 6 months was 10\% in the ruxolitinib group and $39 \%$ in the control group. The median failure-free survival was longer with ruxolitinib than with control $(5.0$ months vs. 1.0 month). The median overall survival was 11.1 months in the ruxolitinib group and 6.5 months in 
the control group (hazard ratio for death 0.83 ). Thrombocytopenia was more common with ruxolitinib $33 \%$ compared to control group $18 \%$, otherwise toxicities and viral infections were similar.

\section{Conclusion}

Acute GVHD develops in 30-75\% of recipients of allo-HSCT despite current GVHD prophylaxis. While majority is grade I-II, 15-20\% are grade III-IV that carries a high morbidity and mortality rate. It is however very encouraging to witness the exciting work being done to prevent or reduce the severity of aGVHD with new prophylaxis combination such as post-HSCT cyclophosphamide. Biomarkers are emerging as added tools that can potentially detect early signs of aGVHD before onset of clinical symptoms, and also to stratify patients into risk groups that may or may not need high dose steroids, which can potentially reduce GVHD treatment-related mortality. As the field evolves, new agents are being evaluated for the prevention and treatment of aGVHD. However, more needs to be done to improve on the morbidity and mortality associated with aGVHD.

\section{Author Contributions}

Manuscript writing: N.S., and Y.E.; Literature review, scientific input and critical comments: N.S., and Y.E.

\section{Competing Interests}

The authors have declared that no competing interests exist.

\section{References}

1. Barker CF, Markmann JF. Historical overview of transplantation. Cold Spring Harb Perspect Med. 2013; 3: a014977.

2. Murphy JB. Factors of resistance to heteroplastic tissue-grafting: Studies in tissue specificity. III. J Exp Med. 1914; 19: 513-522.

3. Billingham RE. The biology of graft-versus-host reactions. Harvery Lect. 1967; 62: 21-78.

4. Ratanatharathorn V, Nash RA, Przepiorka D, Devine SM, Klein JL, Weisdorf D, et al. Phase III study comparing methotrexate and tacrolimus (prograf, FK506) with methotrexate and cyclosporine for graft-versus-host disease prophylaxis after HLA-identical sibling bone marrow transplantation. Blood. 1998; 92: 2303-2314.

5. Nash RA, Antin JH, Karanes C, Fay JW, Avalos BR, Yeager AM, et al. Phase 3 study comparing methotrexate and tacrolimus with methotrexate and cyclosporine for prophylaxis of acute graftversus-host disease after marrow transplantation from unrelated donors. Blood. 2000; 96: 2062-2068.

6. Antin JH, Kim HT, Cutler C, Ho VT, Lee SJ, Miklos DB, et al. Sirolimus, tacrolimus, and low-dose methotrexate for graft-versus-host disease prophylaxis in mismatched related donor or unrelated donor transplantation. Blood. 2003; 102: 1601-1605.

7. Filipovich AH, Weisdorf D, Pavletic S, Socie G, Wingard JR, Lee SJ, et al. National Institutes of Health consensus development project on criteria for clinical trials in chronic graft-versus-host disease: I. Diagnosis and staging working group report. Biol Blood Marrow Transplant. 2005; 11: 945-956. 
8. Jagasia MH, Greinix HT, Arora M, Williams KM, Wolff D, Cowen EW, et al. National Institutes of Health consensus development project on criteria for clinical trials in chronic graft-versus-host disease: I. The 2014 diagnosis and staging working group report. Biol Blood Marrow Transplant. 2015; 21: 389-401.e1.

9. Lee SJ, Wolff D, Kitko C, Koreth J, Inamoto Y, Jagasia M, et al. Measuring therapeutic response in chronic graft-versus-host disease. National Institutes of Health consensus development project on criteria for clinical trials in chronic graft-versus-host disease: IV. The 2014 response criteria working group report. Biol Blood Marrow Transplant. 2015; 21: 984-999.

10. MacMillan ML, Robin M, Harris AC, DeFor TE, Martin PJ, Alousi A, et al. A refined risk score for acute graft-versus-host disease that predicts response to initial therapy, survival, and transplantrelated mortality. Biol Blood Marrow Transplant. 2015; 21: 761-767.

11. Serna DS, Lee SJ, Zhang MJ, Baker KS, Eapen M, Horowitz MM, et al. Trends in survival rates after allogeneic hematopoietic stem-cell transplantation for acute and chronic leukemia by ethnicity in the United States and Canada. J Clin Oncol. 2003; 21: 3754-3760.

12. Wojnar J, Giebel S, Krawczyk-Kulis M, Markiewicz M, Kruzel T, Wylezol I, et al. Acute graft-versushost disease. The incidence and risk factors. Ann Transplant. 2006; 11: 16-23.

13. Jagasia M, Arora M, Flowers ME, Chao NJ, McCarthy PL, Cutler CS, et al. Risk factors for acute GVHD and survival after hematopoietic cell transplantation. Blood. 2012; 119: 296-307.

14. Ferrara JL, Levine JE, Reddy P, Holler E. Graft-versus-host disease. Lancet. 2009; 373: 1550-1561.

15. Deeg HJ. How I treat refractory acute GVHD. Blood. 2007; 109: 4119-4126.

16. Socié G, Blazar BR. Acute graft-versus-host disease: From the bench to the bedside. Blood. 2009; 114: 4327-4336.

17. Graubert TA, Russell JH, Ley TJ. The role of granzyme B in murine models of acute graft-versushost disease and graft rejection. Blood. 1996; 87: 1232-1237.

18. Piguet PF, Grau GE, Allet B, Vassalli P. Tumor necrosis factor/cachectin is an effector of skin and gut lesions of the acute phase of graft-vs.-host disease. J Exp Med. 1987; 166: 1280-1289.

19. Pallett LJ, Davies J, Colbeck EJ, Robertson F, Hansi N, Easom NJ, et al. IL-2high tissue-resident T cells in the human liver: Sentinels for hepatotropic infection. J Exp Med. 2017; 214: 1567-1580.

20. Stelma F, de Niet A, Sinnige MJ, van Dort KA, van Gisbergen KP, Verheij J, et al. Human intrahepatic CD69+ CD8+ T cells have a tissue resident memory $T$ cell phenotype with reduced cytolytic capacity. Sci Rep. 2017; 7: 6172.

21. Iriki H, Adachi T, Mori M, Tanese K, Funakoshi T, Karigane D, et al. Toxic epidermal necrolysis in the absence of circulating $T$ cells: A possible role for resident memory $T$ cells. J Am Acad Dermatol. 2014; 71: e214-e216.

22. Divito SJ, Aaseb $\varnothing$ AT, Matos TR, Hsieh PC, Collin M, Elco CP, et al. Peripheral host T cells survive hematopoietic stem cell transplantation and promote graft-versus-host disease. J Clin Invest. 2020; 130; 4624-4636.

23. Bleakley M, Heimfeld S, Loeb KR, Jones LA, Chaney C, Seropian S, et al. Outcomes of acute leukemia patients transplanted with naive T cell-depleted stem cell grafts. J Clin Invest. 2015; 125: 2677-2689.

24. GLUCKSBERG H, Storb R, Fefer A, Buckner CD, Neiman PE, Clift RA, et al. Clinical manifestations of graft-versus-host in human recipients of marrow from HL-A-matched sibling donors. Transplantation. 1974; 18: 295-304.

25. Przepiorka D, Weisdorf D, Martin P, Klingemann HG, Beatty P, Hows J, et al. 1994 consensus 
conference on acute GVHD grading. Bone Marrow Transplant. 1995; 15: 825-828

26. Rowlings PA, Przepiorka D, Klein JP, Gale RP, Passweg JR, Jean Henslee-Downey P, et al. IBMTR Severity Index for grading acute graft-versus-host disease: Retrospective comparison with Glucksberg grade. Br J Haematol. 1997; 97: 855-864.

27. Harris AC, Young R, Devine S, Hogan WJ, Ayuk F, Bunworasate U, et al. International, multicenter standardization of acute graft-versus-host disease clinical data collection: A report from the Mount Sinai Acute GVHD International Consortium. Biol Blood Marrow Transplant. 2016; 22: 410.

28. MacMillan ML, Weisdorf DJ, Wagner JE, DeFor TE, Burns LJ, Ramsay NK, et al. Response of 443 patients to steroids as primary therapy for acute graft-versus-host disease: Comparison of grading systems. Biol Blood Marrow Transplant. 2002; 8: 387-394.

29. Schoemans HM, Lee SJ, Ferrara JL, Wolff D, Levine JE, Schultz KR, et al. EBMT-NIH-CIBMTR Task Force position statement on standardized terminology \& guidance for graft-versus-host disease assessment. Bone Marrow Transplant. 2018; 53: 1401-1415.

30. Remberger $M$, Ringden $O$, Markling L. TNF alpha levels are increased during bone marrow transplantation conditioning in patients who develop acute GVHD. Bone Marrow Transplant. 1995; 15: 99-104.

31. Liu D, Yan C, Xu L, Wang Y, Han W, Zhang $X$, et al. Diarrhea during the conditioning regimen is correlated with the occurrence of severe acute graft-versus-host disease through systemic release of inflammatory cytokines. Biol Blood Marrow Transplant. 2010; 16: 1567-1575.

32. Paczesny S, Krijanovski OI, Braun TM, Choi SW, Clouthier SG, Kuick R, et al. A biomarker panel for acute graft-versus-host disease. Blood. 2009; 113: 273-278.

33. Harris AC, Ferrara JL, Levine JE. Advances in predicting acute GVHD. Br J Haematol. 2013; 160: 288-302.

34. Ferrara JL, Harris AC, Greenson JK, Braun TM, Holler E, Teshima T, et al. Regenerating isletderived 3-alpha is a biomarker of gastrointestinal graft-versus-host disease. Blood. 2011; 118: 6702-6708.

35. Harris AC, Ferrara JL, Braun TM, Holler E, Teshima T, Levine JE, et al. Plasma biomarkers of lower gastrointestinal and liver acute GVHD. Blood. 2012; 119: 2960-2963.

36. Pastorelli L, Garg RR, Hoang SB, Spina L, Mattioli B, Scarpa M, et al. Epithelial-derived IL-33 and its receptor ST2 are dysregulated in ulcerative colitis and in experimental Th1/Th2 driven enteritis. Proc Natl Acad Sci U S A. 2010; 107: 8017-8022.

37. Srinagesh HK, Levine JE, Ferrara JL. Biomarkers in acute graft-versus-host disease: New insights. Ther Adv Hematol. 2019; 10: 2040620719891358.

38. Levine JE, Braun TM, Harris AC, Holler E, Taylor A, Miller H, et al. A prognostic score for acute graft-versus-host disease based on biomarkers: A multicentre study. Lancet Haematol. 2015; 2: e21-e29.

39. Pidala J, Hamadani M, Dawson P, Martens M, Alousi AM, Jagasia M, et al. Randomized multicenter trial of sirolimus vs prednisone as initial therapy for standard-risk acute GVHD: The BMT CTN 1501 trial. Blood. 2020; 135: 97-107.

40. Champlin RE, Schmitz N, Horowitz MM, Chapuis B, Chopra R, Cornelissen JJ, et al. Blood stem cells compared with bone marrow as a source of hematopoietic cells for allogeneic transplantation. Blood. 2000; 95: 3702-3709.

41. Ringdén O, Pavletic SZ, Anasetti C, Barrett AJ, Wang T, Wang D, etal. The graft-versus-leukemia 
effect using matched unrelated donors is not superior to HLA-identical siblings for hematopoietic stem cell transplantation. Blood. 2009; 113: 3110-3118.

42. Lee SJ, Klein J, Haagenson M, Baxter-Lowe LA, Confer DL, Eapen M, et al. High-resolution donorrecipient HLA matching contributes to the success of unrelated donor marrow transplantation. Blood. 2007; 110: 4576-4583.

43. Ruutu T, Gratwohl A, De Witte T, Afanasyev B, Apperley J, Bacigalupo A, et al. Prophylaxis and treatment of GVHD: EBMT-ELN working group recommendations for a standardized practice. Bone Marrow Transplant. 2014; 49: 168-173.

44. Lee SE, Cho BS, Kim JH, Yoon JH, Shin SH, Yahng SA, et al. Risk and prognostic factors for acute GVHD based on NIH consensus criteria. Bone Marrow Transplant. 2013; 48: 587-592.

45. Chao NJ. Graft-versus-host disease: The viewpoint from the donor T cell. Biol Blood Marrow Transplant. 1997; 3: 1-10.

46. Goker H, Haznedaroglu IC, Chao NJ. Acute graft-vs-host disease: Pathobiology and management. Exp Hematol. 2001; 29: 259-277.

47. Hiraoka A, Ohashi Y, Okamoto S, Moriyama Y, Nagao T, Kodera Y, et al. Phase III study comparing tacrolimus (FK506) with cyclosporine for graft-versus-host disease prophylaxis after allogeneic bone marrow transplantation. Bone Marrow Transplant. 2001; 28: 181-185.

48. Kanda Y, Kobayashi T, Mori T, Tanaka M, Nakaseko C, Yokota A, et al. A randomized controlled trial of cyclosporine and tacrolimus with strict control of blood concentrations after unrelated bone marrow transplantation. Bone Marrow Transplant. 2016; 51: 103-109.

49. Finke J, Bethge WA, Schmoor C, Ottinger HD, Stelljes M, Zander AR, et al. Standard graft-versushost disease prophylaxis with or without anti-T-cell globulin in haematopoietic cell transplantation from matched unrelated donors: A randomised, open-label, multicentre phase 3 trial. Lancet Oncol. 2009; 10: 855-864.

50. Finke J, Schmoor C, Bethge WA, Ottinger $H$, Stelljes $M$, Volin L, et al. Long-term outcomes after standard graft-versus-host disease prophylaxis with or without anti-human-T-lymphocyte immunoglobulin in haemopoietic cell transplantation from matched unrelated donors: Final results of a randomised controlled trial. Lancet Haematol. 2017; 4: e293-e301.

51. Walker I, Panzarella T, Couban S, Couture F, Devins G, Elemary M, et al. Pretreatment with antithymocyte globulin versus no anti-thymocyte globulin in patients with haematological malignancies undergoing haemopoietic cell transplantation from unrelated donors: A randomised, controlled, open-label, phase 3, multicentre trial. Lancet Oncol. 2016; 17: 164-173.

52. Bolaños-Meade J, Reshef R, Fraser R, Fei M, Abhyankar S, Al-Kadhimi Z, et al. Three prophylaxis regimens (tacrolimus, mycophenolate mofetil, and cyclophosphamide; tacrolimus, methotrexate, and bortezomib; or tacrolimus, methotrexate, and maraviroc) versus tacrolimus and methotrexate for prevention of graft-versus-host disease with haemopoietic cell transplantation with reduced-intensity conditioning: A randomised phase 2 trial with a nonrandomised contemporaneous control group (BMT CTN 1203). Lancet Haematol. 2019; 6: e132e143.

53. Cutler C, Antin JH. Sirolimus for GVHD prophylaxis in allogeneic stem cell transplantation. Bone Marrow Transplant. 2004; 34: 471-476.

54. Cutler C, Logan B, Nakamura R, Johnston L, Choi S, Porter D, et al. Tacrolimus/sirolimus vs tacrolimus/methotrexate as GVHD prophylaxis after matched, related donor allogeneic HCT. Blood. 2014; 124: 1372-1377. 
55. Kennedy GA, Tey SK, Buizen L, Varelias A, Gartlan KH, Curley C, et al. A phase 3 double-blind study of the addition of tocilizumab versus placebo to Cyclosporin/Methotrexate GVHD prophylaxis. Blood. 2021. Doi: 10.1182/blood.2020009050.

56. Watkins B, Qayed M, McCracken C, Bratrude B, Betz K, Suessmuth Y, et al. Phase II trial of costimulation blockade with Abatacept for prevention of acute GVHD. J Clin Oncol. 2021. Doi: 10.1200/JCO.20.01086.

57. Storb R, Deeg HJ, Whitehead J, Appelbaum F, Beatty P, Bensinger W, et al. Methotrexate and cyclosporine compared with cyclosporine alone for prophylaxis of acute graft versus host disease after marrow transplantation for leukemia. N Engl J Med. 1986; 314: 729-735.

58. Martin PJ, Schoch G, Fisher L, Byers V, Appelbaum FR, McDonald GB, et al. A retrospective analysis of therapy for acute graft-versus-host disease: Secondary treatment. Blood. 1991; 77: 1821-1828.

59. Ram R, Gafter-Gvili A, Yeshurun M, Paul M, Raanani P, Shpilberg O. Prophylaxis regimens for GVHD: Systematic review and meta-analysis. Bone Marrow Transplant. 2009; 43: 643-653.

60. Koreth J, Stevenson KE, Kim HT, McDonough SM, Bindra B, Armand P, et al. Bortezomib-based graft-versus-host disease prophylaxis in HLA-mismatched unrelated donor transplantation. J Clin Oncol. 2012; 30: 3202-3208.

61. Ganetsky A, Shah A, Miano TA, Hwang WT, He J, Loren AW, et al. Higher tacrolimus concentrations early after transplant reduce the risk of acute GVHD in reduced-intensity allogeneic stem cell transplantation. Bone Marrow Transplant. 2016; 51: 568-572.

62. Craddock C, Nagra S, Peniket A, Brookes C, Buckley L, Nikolousis E, et al. Factors predicting longterm survival after T-cell depleted reduced intensity allogeneic stem cell transplantation for acute myeloid leukemia. Haematologica. 2010; 95: 989-995.

63. Lint V. The combined effect of total body irradiation (TBI) and cyclosporin A (CyA) on the risk of relapse in patients with acute myeloid leukaemia undergoing allogeneic bone marrow transplantation. Br J Haematol. 2000; 108: 99-104.

64. Bacigalupo AV, Van Lint MT, Occhini D, Gualandi F, Lamparelli T, Sogno G, Tet al. Increased risk of leukemia relapse with high-dose cyclosporine A after allogeneic marrow transplantation for acute leukemia. Blood. 1991; 77: 1423-1428.

65. Locatelli F, Zecca M, Rondelli R, Bonetti F, Dini G, Prete A, et al. Graft versus host disease prophylaxis with low-dose cyclosporine-A reduces the risk of relapse in children with acute leukemia given HLA-identical sibling bone marrow transplantation: Results of a randomized trial. Blood. 2000; 95: 1572-1579.

66. Wingard JR, Nash RA, Przepiorka D, Klein JL, Weisdorf DJ, Fay JW, et al. Relationship of tacrolimus (FK506) whole blood concentrations and efficacy and safety after HLA-identical sibling bone marrow transplantation. Biol Blood Marrow Transplant. 1998; 4: 157-163.

67. Przepiorka D, Nash RA, Wingard JR, Zhu J, Maher RM, Fitzsimmons WE, et al. Relationship of tacrolimus whole blood levels to efficacy and safety outcomes after unrelated donor marrow transplantation. Biol Blood Marrow Transplant. 1999; 5: 94-97.

68. Mori T, Kato J, Shimizu T, Aisa Y, Nakazato T, Yamane A, et al. Effect of early posttransplantation tacrolimus concentration on the development of acute graft-versus-host disease after allogeneic hematopoietic stem cell transplantation from unrelated donors. Biol Blood Marrow Transplant. 2012; 18: 229-234.

69. Hagen PA, Kobrinski D, Al-Mansour Z, Tsai SB, Parthasarathy M, Kliethermes S, et al. Early post- 
transplantation tacrolimus levels correlate with acute graft-versus-host disease in allogeneic hematopoietic stem cell transplantation from related and unrelated donors. Blood. 2016; 128; 3429.

70. Abouelnasr A, Roy J, Cohen S, Kiss T, Lachance S. Defining the role of sirolimus in the management of graft-versus-host disease: From prophylaxis to treatment. Biol Blood Marrow Transplant. 2013; 19: 12-21.

71. Kirken RA, Wang YL. Molecular actions of sirolimus: Sirolimus and mTor. Transplant Proc. 2003; 35: S227-S230.

72. Monti P, Mercalli A, Leone BE, Allavena P, Piemonti L. Rapamycin impairs antigen uptake of human dendritic cells1. Transplantation. 200; 75: 137-145.

73. Hackstein H, Taner T, Zahorchak AF, Morelli AE, Logar AJ, Gessner A, et al. Rapamycin inhibits IL4 -induced dendritic cell maturation in vitro and dendritic cell mobilization and function in vivo. Blood. 2003; 101: 4457-4463.

74. Chiang PH, Wang L, Liang Y, Liang X, Qian S. Inhibition of IL-12 signaling Stat4/IFN- $\gamma$ pathway by rapamycin is associated with impaired dendritic cell function. Transplant Proc. 2002; 34: 13941395.

75. Woltman AM, van der Kooij SW, Coffer PJ, Offringa R, Daha MR, van Kooten C. Rapamycin specifically interferes with GM-CSF signaling in human dendritic cells, leading to apoptosis via increased p27KIP1 expression. Blood. 2003; 101: 1439-1445.

76. Sehgal SN. Sirolimus: Its discovery, biological properties, and mechanism of action. Transplant Proc. 2003; 35: S7-S14.

77. Ciancio G, Burke GW, Gaynor JJ, Mattiazzi A, Roth D, Kupin W, et al. A randomized long-term trial of tacrolimus and sirolimus versus tacrolimus and mycophenolate mofetil versus cyclosporine (NEORAL) and sirolimus in renal transplantation. I. Drug interactions and rejection at one year. Transplantation. 2004; 77: 244-251.

78. Koenen HJ, Michielsen EC, Verstappen J, Fasse E, Joosten I. Superior T-cell suppression by rapamycin and FK506 over rapamycin and cyclosporine $A$ because of abrogated cytotoxic Tlymphocyte induction, impaired memory responses, and persistent apoptosis. Transplantation. 2003; 75: 1581-1590.

79. Törlén J, Ringdén $O$, Garming-Legert K, Ljungman P, Winiarski J, Remes K, et al. A prospective randomized trial comparing cyclosporine/methotrexate and tacrolimus/sirolimus as graftversus-host disease prophylaxis after allogeneic hematopoietic stem cell transplantation. Haematologica. 2016; 101: 1417-1425.

80. Cutler C, Kim HT, Hochberg E, Ho V, Alyea E, Lee SJ, et al. Sirolimus and tacrolimus without methotrexate as graft-versus-host disease prophylaxis after matched related donor peripheral blood stem cell transplantation. Biol Blood Marrow Transplant. 2004; 10: 328-336.

81. Alyea EP, Li S, Kim HT, Cutler C, Ho V, Soiffer RJ, et al. Sirolimus, tacrolimus, and low-dose methotrexate as graft-versus-host disease prophylaxis in related and unrelated donor reducedintensity conditioning allogeneic peripheral blood stem cell transplantation. Biol Blood Marrow Transplant. 2008; 14: 920-926.

82. Cutler C, Li S, Ho VT, Koreth J, Alyea E, Soiffer RJ, et al. Extended follow-up of methotrexate-free immunosuppression using sirolimus and tacrolimus in related and unrelated donor peripheral blood stem cell transplantation. Blood. 2007; 109: 3108-3114.

83. Cutler C, Stevenson K, Kim HT, Richardson P, Ho VT, Linden E, et al. Sirolimus is associated with 
veno-occlusive disease of the liver after myeloablative allogeneic stem cell transplantation. Blood. 2008; 112: 4425-4431.

84. Kahan BD, Rapmune US Study Group. Efficacy of sirolimus compared with azathioprine for reduction of acute renal allograft rejection: A randomised multicentre study. Lancet. 2000; 356: 194-202.

85. MacDonald AS. A worldwide, phase III, randomized, controlled, safety and efficacy study of a sirolimus/cyclosporine regimen for prevention of acute rejection in recipients of primary mismatched renal allografts. Transplantation. 2001; 71: 271-280.

86. Podder H, Stepkowski SM, Napoli KL, Clark J, Verani RR, Chou TC, et al. Pharmacokinetic interactions augment toxicities of sirolimus/cyclosporine combinations. J Am Soc Nephrol. 2001; 12: 1059-1071.

87. de Mattos AM, Olyaei AJ, Bennett WM. Nephrotoxicity of immunosuppressive drugs: Long-term consequences and challenges for the future. Am J Kidney Dis. 2000; 35: 333-346.

88. Robson M, Côte I, Abbs I, Koffman G, Goldsmith D. Thrombotic micro-angiopathy with sirolimusbased immunosuppression: Potentiation of calcineurin-inhibitor-induced endothelial damage? Am J Transplant. 2003; 3: 324-327.

89. Cutler C, Henry NL, Magee C, Li S, Kim HT, Alyea E, et al. Sirolimus and thrombotic microangiopathy after allogeneic hematopoietic stem cell transplantation. Biol Blood Marrow Transplant. 2005; 11: 551-557.

90. Barone GW, Gurley BJ, Abul-Ezz SR, Gökden N. Sirolimus-induced thrombotic microangiopathy in a renal transplant recipient. Am J Kidney Dis. 2003; 42: 202-206.

91. Luznik L, O'Donnell PV, Symons HJ, Chen AR, Leffell MS, Zahurak M, et al. HLA-haploidentical bone marrow transplantation for hematologic malignancies using nonmyeloablative conditioning and high-dose, posttransplantation cyclophosphamide. Biol Blood Marrow Transplant. 2008; 14: 641-650.

92. Brunstein CG, Fuchs EJ, Carter SL, Karanes C, Costa LJ, Wu J, et al. Alternative donor transplantation after reduced intensity conditioning: Results of parallel phase 2 trials using partially HLA-mismatched related bone marrow or unrelated double umbilical cord blood grafts. Blood. 2011; 118: 282-288.

93. Luznik L, Bolaños-Meade J, Zahurak M, Chen AR, Smith BD, Brodsky R, et al. High-dose cyclophosphamide as single-agent, short-course prophylaxis of graft-versus-host disease. Blood. 2010; 115: 3224-3230.

94. Kanakry CG, Tsai HL, Bolaños-Meade J, Smith BD, Gojo I, Kanakry JA, et al. Single-agent GVHD prophylaxis with posttransplantation cyclophosphamide after myeloablative, HLA-matched BMT for AML, ALL, and MDS. Blood. 2014; 124: 3817-3827.

95. Kanakry CG, Bolaños-Meade J, Kasamon YL, Zahurak M, Durakovic N, Furlong T, et al. Low immunosuppressive burden after HLA-matched related or unrelated BMT using posttransplantation cyclophosphamide. Blood. 2017; 129: 1389-1393.

96. Majzner RG, Mogri H, Varadhan R, Brown P, Cooke KR, Bolaños-Meade J, et al. Posttransplantation cyclophosphamide after bone marrow transplantation is not associated with an increased risk of donor-derived malignancy. Biol Blood Marrow Transplant. 2017; 23: 612-617.

97. O'donnell PV, Luznik L, Jones RJ, Vogelsang GB, Leffell MS, Phelps M, et al. Nonmyeloablative bone marrow transplantation from partially HLA-mismatched related donors using posttransplantation cyclophosphamide. Biol Blood Marrow Transplant. 2002; 8: 377-386. 
98. Mielcarek M, Furlong T, O’Donnell PV, Storer BE, McCune JS, Storb R, et al. Posttransplantation cyclophosphamide for prevention of graft-versus-host disease after HLA-matched mobilized blood cell transplantation. Blood. 2016; 127: 1502-1508.

99. Crawley C, Lalancette M, Szydlo R, Gilleece M, Peggs K, Mackinnon S, et al. Outcomes for reduced-intensity allogeneic transplantation for multiple myeloma: An analysis of prognostic factors from the Chronic Leukaemia Working Party of the EBMT. Blood. 2005; 105: 4532-4539.

100.Salem G, Ruppert AS, Elder P, Hofmeister CC, Benson DM, Penza S, et al. Lower dose of antithymocyte globulin does not increase graft-versus-host disease in patients undergoing reduced-intensity conditioning allogeneic hematopoietic stem cell transplant. Leuk Lymphoma. 2015; 56: 1058-1065.

101. Hamadani M, Blum W, Phillips G, Elder P, Andritsos L, Hofmeister C, et al. Improved nonrelapse mortality and infection rate with lower dose of antithymocyte globulin in patients undergoing reduced-intensity conditioning allogeneic transplantation for hematologic malignancies. Biol Blood Marrow Transplant. 2009; 15: 1422-1430.

102. Bacigalupo A, Lamparelli T, Barisione G, Bruzzi P, Guidi S, Alessandrino PE, et al. Thymoglobulin prevents chronic graft-versus-host disease, chronic lung dysfunction, and late transplant-related mortality: long-term follow-up of a randomized trial in patients undergoing unrelated donor transplantation. Biol Blood Marrow Transplant. 2006; 12: 560-565.

103. Remberger M, Storer B, Ringden O, Anasetti C. Association between pretransplant Thymoglobulin and reduced non-relapse mortality rate after marrow transplantation from unrelated donors. Bone Marrow Transplant. 2002; 29: 391-397.

104. Remberger M, Svahn BM, Mattsson J, Ringdén O. Dose study of thymoglobulin during conditioning for unrelated donor allogeneic stem-cell transplantation. Transplantation. 2004; 78: 122-127.

105. Issa H, Sharma N, Zhao Q, Ruppert AS, Elder P, Benson DM, et al. Comparison of two doses of antithymocyte globulin in reduced-intensity conditioning allogeneic hematopoietic stem cell transplantation. Biol Blood Marrow Transplant. 2019; 25: 1993-2001.

106.Zand MS, Vo T, Huggins J, Felgar R, Liesveld J, Pellegrin T, et al. Polyclonal rabbit antithymocyte globulin triggers B-cell and plasma cell apoptosis by multiple pathways. Transplantation. 2005; 79: 1507-1515.

107.Zand MS, Vo T, Pellegrin T, Felgar R, Liesveld JL, Ifthikharuddin JJ, et al. Apoptosis and complement-mediated lysis of myeloma cells by polyclonal rabbit antithymocyte globulin. Blood. 2006; 107: 2895-2903.

108. Mohty M. Mechanisms of action of antithymocyte globulin: T-cell depletion and beyond. Leukemia. 2007; 21: 1387-1394.

109. Baron F, Labopin M, Niederwieser D, Vigouroux S, Cornelissen JJ, Malm C, et al. Impact of graftversus-host disease after reduced-intensity conditioning allogeneic stem cell transplantation for acute myeloid leukemia: A report from the Acute Leukemia Working Party of the European group for blood and marrow transplantation. Leukemia. 2012; 26: 2462-2468.

110. Mohty M, Faucher C, Vey N, Stoppa AM, Viret F, Chabbert I, et al. High rate of secondary viral and bacterial infections in patients undergoing allogeneic bone marrow mini-transplantation. Bone Marrow Transplant. 2000; 26: 251-255.

111. Van Lint MT, Uderzo C, Locasciulli A, Majolino I, Scime R, Locatelli F, et al. Early treatment of acute graft-versus-host disease with high-or low-dose 6-methylprednisolone: A multicenter 
randomized trial from the Italian Group for Bone Marrow Transplantation. Blood. 1998; 92: 2288-2293.

112. Martin PJ, Rizzo JD, Wingard JR, Ballen K, Curtin PT, Cutler C, et al. First-and second-line systemic treatment of acute graft-versus-host disease: Recommendations of the American Society of Blood and Marrow Transplantation. Biol Blood Marrow Transplant. 2012; 18: 1150-1163.

113. Bolaños-Meade J, Logan BR, Alousi AM, Antin JH, Barowski K, Carter SL, et al. Phase 3 clinical trial of steroids/mycophenolate mofetil vs steroids/placebo as therapy for acute GVHD: BMT CTN 0802. Blood. 2014; 124: 3221-3227.

114. Alousi AM, Weisdorf DJ, Logan BR, Bolaños-Meade J, Carter S, DiFronzo N, et al. Etanercept, mycophenolate, denileukin, or pentostatin plus corticosteroids for acute graft-versus-host disease: A randomized phase 2 trial from the Blood and Marrow Transplant Clinical Trials Network. Blood. 2009; 114: 511-517.

115. Hou C, Dou L, Jia M, Li F, Wang S, Gao X, et al. Ruxolitinib combined with corticosteroids as firstline therapy for acute graft-versus-host disease in haploidentical peripheral blood stem cell transplantation recipients. Cell Ther Transplant. 2021; 27: 75.e1-75.e10.

116. Rashidi A, DiPersio JF, Sandmaier BM, Colditz GA, Weisdorf DJ. Steroids versus steroids plus additional agent in frontline treatment of acute graft-versus-host disease: A systematic review and meta-analysis of randomized trials. Biol Blood Marrow Transplant. 2016; 22: 1133-1137.

117. Kekre N, Kim HT, Hofer J, Ho VT, Koreth J, Armand P, et al. Phase II trial of natalizumab with corticosteroids as initial treatment of gastrointestinal acute graft-versus-host disease. Bone Marrow Transplant. 2020. DOI: 10.1038/s41409-020-01049-0.

118. Cragg L, Blazar BR, Defor T, Kolatker N, Miller W, Kersey J, et al. A randomized trial comparing prednisone with antithymocyte globulin/prednisone as an initial systemic therapy for moderately severe acute graft-versus-host disease. Biol Blood Marrow Transplant. 2000; 6: 441447.

119. Lee SJ, Zahrieh D, Agura E, MacMillan ML, Maziarz RT, McCarthy Jr PL, et al. Effect of up-front daclizumab when combined with steroids for the treatment of acute graft-versus-host disease: Results of a randomized trial. Blood. 2004; 104: 1559-1564.

120. Couriel DR, Saliba R, de Lima M, Giralt S, Andersson B, Khouri I, et al. A phase III study of infliximab and corticosteroids for the initial treatment of acute graft-versus-host disease. Biol Blood Marrow Transplant. 2009; 15: 1555-1562.

121. Mielcarek M, Furlong T, Storer BE, Green ML, McDonald GB, Carpenter PA, et al. Effectiveness and safety of lower dose prednisone for initial treatment of acute graft-versus-host disease: $A$ randomized controlled trial. Haematologica. 2015; 100: 842-848.

122. MacMillan ML, DeFor TE, Holtan SG, Rashidi A, Blazar BR, Weisdorf DJ. Validation of Minnesota acute graft-versus-host disease risk score. Haematologica. 2020; 105: 519-524.

123. MacMillan ML, DeFor TE, Weisdorf DJ. What predicts high risk acute graft-versus-host disease (GVHD) at onset? Identification of those at highest risk by a novel acute GVHD risk score. Br J Haematol. 2012; 157: 732-741.

124. Hartwell MJ, Özbek U, Holler E, Renteria AS, Major-Monfried H, Reddy P, et al. An earlybiomarker algorithm predicts lethal graft-versus-host disease and survival. JCI Insight. 2017; 2: e89798.

125. Berger M, Biasin E, Saglio F, Fagioli F. Innovative approaches to treat steroid-resistant or steroid refractory GVHD. Bone Marrow Transplant. 2008; 42: S101-S105. 
126. Garnett C, Apperley JF, Pavlů J. Treatment and management of graft-versus-host disease: Improving response and survival. Ther Adv Hematol. 2013; 4: 366-378.

127. Baker KS, Allen RD, Roths JB, Sidman CL. Kinetic and organ-specific patterns of cytokine expression in acute graft-versus-host disease. Bone Marrow Transplant. 1995; 15: 595-603.

128. Yucebay F, Matthews C, Puto M, Li J, William B, Jaglowski SM, et al. Tocilizumab as first-line therapy for steroid-refractory acute graft-versus-host-disease: Analysis of a single-center experience. Leuk Lymphoma. 2019; 60: 2223-2229.

129. Roddy JV, Haverkos BM, McBride A, Leininger KM, Jaglowski S, Penza S, et al. Tocilizumab for steroid refractory acute graft-versus-host disease. Leuk Lymphoma. 2016; 57: 81-85.

130. DiMaggio E. Acute graft-versus-host disease: Emerging insights and updates into detection, prevention, and treatment. Pharmacotherapy. 2020; 40: 788-807.

131. Chen X, Wang C, Yin J, Xu J, Wei J, Zhang Y. Efficacy of mesenchymal stem cell therapy for steroidrefractory acute graft-versus-host disease following allogeneic hematopoietic stem cell transplantation: A systematic review and meta-analysis. PLoS ONE. 2015; 10: e0136991.

132. Schroeder MA, Khoury HJ, Jagasia M, Ali H, Schiller GJ, Staser K, et al. A phase 1 trial of itacitinib, a selective JAK1 inhibitor, in patients with acute graft-versus-host disease. Blood Adv. 2020; 4: 1656-1669.

133.Jagasia M, Perales MA, Schroeder MA, Ali H, Shah NN, Chen YB, et al. Ruxolitinib for the treatment of steroid-refractory acute GVHD (REACH1): A multicenter, open-label phase 2 trial. Blood. 2020; 135: 1739-1749.

134.Zeiser R, von Bubnoff N, Butler J, Mohty M, Niederwieser D, Or R, et al. Ruxolitinib for glucocorticoid-refractory acute graft-versus-host disease. N Engl J Med. 2020; 382: 1800-1810.

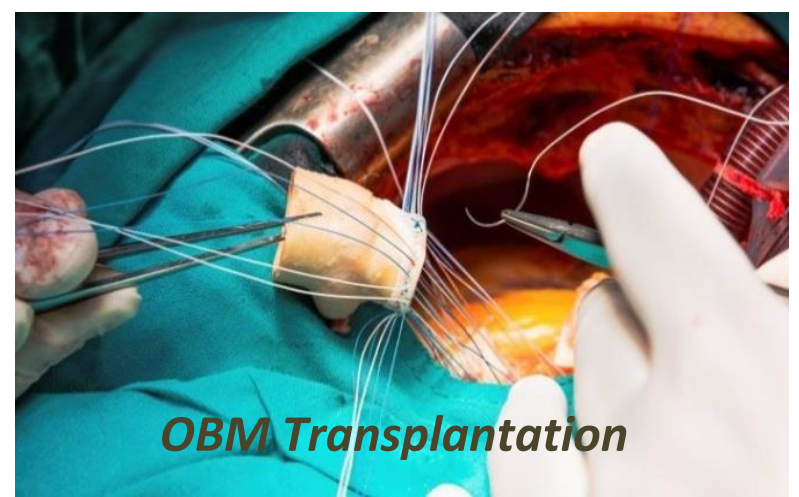

Enjoy OBM Transplantation by:

1. Submitting a manuscript

2. Joining in volunteer reviewer bank

3. Joining Editorial Board

4. Guest editing a special issue

For more details, please visit:

http://www.lidsen.com/journals/transplantation 